WAS THE FEDERAL RESERVE FETTERED?

DEVALUATION EXPECTATIONS IN THE 1932 MONETARY EXPANSION

\author{
Chang-Tai Hsieh \\ Christina D. Romer \\ Working Paper 8113 \\ http://www.nber.org/papers/w8113 \\ NATIONAL BUREAU OF ECONOMIC RESEARCH \\ 1050 Massachusetts Avenue \\ Cambridge, MA 02138 \\ February 2001
}

We are grateful to Ben Bernanke, Barry Eichengreen, Richard Grossman, Allan Meltzer, David Romer, Alan Taylor, and Peter Temin for extremely helpful comments and suggestions; to the National Science Foundation for financial support; and to Jeff Paulsen, Van Standifer, and Jake Wetzel for research assistance. The views expressed herein are those of the authors and not necessarily those of the National Bureau of Economic Research.

(C) 2001 by Chang-Tai Hsieh and Christina D. Romer. All rights reserved. Short sections of text, not to exceed two paragraphs, may be quoted without explicit permission provided that full credit, including (C) notice, is given to the source. 
Was the Federal Reserve Fettered?

Devaluation Expectations in the 1932 Monetary Expansion

Chang-Tai Hsieh and Christina D. Romer

NBER Working Paper No. 8113

February 2001

JEL No. N1, E5, F3

\begin{abstract}
$\underline{\text { ABSTRACT }}$
A key question about the Great Depression is whether expansionary monetary policy in the United States would have led to a loss of confidence in the U. S. commitment to the gold standard. This paper uses the $\$ 1$ billion expansionary open market operation undertaken in the spring of 1932 as a crucial case study of the link between monetary expansion and expectations of devaluation. Data on forward exchange rates are used to measure expectations of devaluation during this episode. We find little evidence that the large monetary expansion led investors to believe that the United States would devalue. The financial press and the records of the Federal Reserve also show little evidence of expectations of devaluation or fear of a speculative attack. We find that a flawed model of the effects of monetary policy and conflict among the twelve Federal Reserve banks, rather than concern about the gold standard, led the Federal Reserve to suspend the expansionary policy in the summer of 1932.
\end{abstract}

Chang-Tai Hsieh

Woodrow Wilson School

406 Robertson Hall

Princeton University

Princeton, NJ 08544

chsieh@princeton.edu
Christina D. Romer

Department of Economics

University of California, Berkeley

Berkeley, CA 94720

and NBER

cromer@econ.berkeley.edu 


\section{WAS THE FEDERAL RESERVE FETTERED? \\ Devaluation Expectations in the 1932 Monetary Expansion}

The Federal Reserve's failure to respond to banking panics and plummeting output during the Great Depression is surely one of the great mysteries of the 1930s. Why would a central bank, explicitly formed just fifteen years earlier to deal with financial instability, do so little during the worst financial and economic crisis of the twentieth century? In his influential book Golden Fetters, Barry Eichengreen (1992) argues that adherence to the gold standard was crucial. The Federal Reserve could not act because doing so might lead to a loss of convertibility of the dollar into gold.

Eichengreen's crucial contribution is to point out the importance of beliefs about the U.S. commitment to the gold standard. Throughout most of the early 1930s, and especially after the passage of the Glass-Steagall Act of 1932, U.S. holdings of "free gold" (that is, gold available to back increases in the money supply) were very large. From this fact, many scholars have concluded that the Federal Reserve could have increased the American money supply without threatening the U.S. adherence to the gold standard. Friedman and Schwartz (1963) and, more recently, Bordo, Choudhri, and Schwartz (1999) present calculations that suggest that expansionary policy would have led to relatively modest gold losses working through the normal specie-flow mechanism. As a result, they argue that the Federal Reserve could have expanded substantially in 1930 and 1931 without causing the United States to hit the gold cover ratio. But Eichengreen argues that such expansionary policies would have led to expectations of devaluation. Indeed, if monetary expansion had led to a severe loss of credibility, the United States could have experienced a catastrophic loss of gold in a very short time. Eichengreen's view that the risk of a speculative attack was a fundamental constraint on monetary policy in the Depression is echoed by Temin (1989), Bernanke (1993, 1995), and others.

This paper tests the link between American monetary policy and devaluation expectations 
during the Great Depression. It does so by examining in detail the open market purchase program of 1932. In the spring of 1932, the Federal Reserve embarked on a program of rapid monetary expansion. In just fourteen weeks, the Federal Reserve purchased \$936 million worth of U.S. government securities, more than doubling its holdings of government debt. ${ }^{1}$ The open market operations were equivalent to 12 percent of the stock of high-powered money in the month before the program began. ${ }^{2}$ The next largest net purchase of government securities over a fourteen-week period between 1922 and 1933 was $\$ 374$ million, which occurred in late 1929 . Thus, the 1932 open market purchase program was nearly three times as large as the largest expansion in the previous decade. We believe this episode provides a crucial laboratory for testing whether monetary expansion could have occurred at other times and on a larger scale during the Great Depression without causing expectations of devaluation, and hence without jeopardizing the gold standard.

Our analysis of devaluation expectations during the 1932 episode proceeds along two lines. One examines empirical estimates of devaluation expectations derived from forward exchange rates. If the Federal Reserve's actions led investors to doubt the U.S. commitment to the gold standard, this should show up as a rise in the forward dollar exchange rate relative to the spot rate. We calculate a measure of expected dollar devaluation relative to the currencies of four countries widely thought to have been firmly attached to gold during this period. We then look for systematic changes around the time of the 1932 open market purchase program.

We find remarkably little evidence of an effect of the monetary expansion on expectations of devaluation. There was a small rise in expectations of devaluation in the middle of the open market purchase program, but it does not seem to be related to news about the monetary expansion. Fears did not rise until well after the program was underway, and declined before there was any indication the

\footnotetext{
${ }^{1}$ The data on the Federal Reserve's balance sheet are from the Twentieth Annual Report of the Federal Reserve Board (1933, Table 4, pp. 78-89).

${ }^{2}$ According to Friedman and Schwartz (1963, Table B-3, p. 803), high-powered money in March 1932 was $\$ 7.539$ billion.
} 
program was going to stop. From this we conclude that there is little evidence that the U.S. monetary expansion of 1932 led to fears of devaluation.

The second line of analysis examines narrative evidence on expectations of devaluation and the motivations of the Federal Reserve. We examine the historical record to see if there were expectations of devaluation or fear of a speculative attack among either Federal Reserve officials or outside observers. We find little evidence of either of these sentiments. The Commercial and Financial Chronicle worried greatly about a loss of credibility when the expansionary program was first announced, but then became more sanguine as the expansion continued. The leaders of the Federal Reserve also expressed little concern about a loss of credibility. Indeed, they took gold outflows to be a sign that expansionary open market operations were needed, not as a sign of trouble.

If the Federal Reserve did not fear a speculative attack on the dollar in the summer of 1932 , then why did it stop the program while the economy was still so deeply depressed? Our reading of the Federal Reserve records suggests that a misguided model of the economy, together with infighting among the twelve Federal Reserve banks, accounts for the end of concerted action. The Federal Reserve stopped largely because it thought it had accomplished its goal and because it was difficult to achieve consensus among the twelve Federal Reserve banks.

Our analysis of the link between monetary expansion and devaluation expectations during the Great Depression is organized as follows. Section I describes the 1932 experiment and discusses public perceptions of the Federal Reserve's actions. Section II discusses the data on forward exchange rates and the information they provide about the credibility of the U.S. commitment to the gold standard. Section III presents empirical analysis of the response of expectations of devaluation to the monetary experiment of 1932. Section IV discusses the narrative evidence on whether a speculative attack was feared by the Federal Reserve or market participants during the 1932 episode. It also discusses the reasons that the Federal Reserve abandoned the program. Finally, Section V discusses the broader implications of our findings for the role of monetary policy in the Great Depression. 


\section{THE 1932 EXPERIMENT}

\section{A. Chronology of Events}

In January 1932, there were signs that the Federal Reserve was considering embarking on an expansionary monetary policy. In his annual address to the New York State Bankers Association on January 8, George L. Harrison, Governor of the Federal Reserve Bank of New York, bemoaned the decline of bank credit over the last few years. He went on to argue that to arrest this decline, "the Federal Reserve banks are in a position at the present time and on the basis of their present gold supply to expand Federal Reserve credit to their members by some $31 / 2$ billion dollars."3 At its meeting on January 11 and 12, the Open Market Policy Conference, the Federal Reserve's system-wide policy forum during this period, authorized the purchase of $\$ 200$ million of government securities. ${ }^{4}$ The authority granted, however, was never used. Instead, the Federal Reserve banks' holdings of government securities declined by $\$ 25$ million over the next six weeks.

In February 1932, Congress passed the Glass-Steagall Act, which allowed the Federal Reserve to use government securities as backing for the 60 percent of Federal Reserve notes not required to be backed by gold. Before this, the Federal Reserve had needed to hold some gold above the required 40 percent because it did not have enough other assets that were eligible to back notes. The Glass-Steagall Act, together with the Federal Reserve's large holdings of government debt, meant that the gold above the statutory minimum was now entirely "free gold." At its meeting on February 24 and 25, the Open Market Policy Conference (hereafter OMPC) authorized the purchase of \$250 million in government securities at a rate of approximately $\$ 25$ million per week. ${ }^{5}$ The Federal Reserve banks used this

\footnotetext{
${ }^{3}$ Harrison Papers, "Introductory Remarks by Governor Harrison to the New York State Bankers Association," January 8, 1932.

${ }^{4}$ Harrison Papers, "Minutes of the Meeting of the Open Market Policy Conference," January 11 and $12,1932$.

${ }^{5}$ Harrison Papers, "Minutes of the Meeting of Governors," February 24 and 25, 1932.
} 
authority to purchase $\$ 144$ million in government securities over the next seven weeks.

At its next meeting on April 12, the OMPC decided to dramatically accelerate the program of monetary expansion. At this meeting, the OMPC authorized the Executive Committee to purchase an additional $\$ 500$ million in government securities. In addition, it recommended "that these purchases, at least in the initial weeks, should be at a rate as rapid as may be practicable and if possible should amount to 100 million in the current statement week." ${ }^{\circ}$ The Federal Reserve banks purchased exactly $\$ 500$ million of government securities over the next five weeks. The next meeting of the OMPC on May 17 authorized the purchase of an additional $\$ 500$ million of government securities. ${ }^{7}$ However, after May 21 , the scale of the purchases was reduced to approximately $\$ 60$ million per week.

By mid-June, there were signs that the Federal Reserve did not intend to continue the open market operations at even this reduced rate. At its meeting on June 16, the Executive Committee of the OMPC unanimously agreed that "sufficient purchases of government securities should be made to keep excess reserves of member banks at a figure between $\$ 250,000,000$ and $\$ 300,000,000$," a range that encompassed the prevailing level of excess reserves. ${ }^{8}$ Nevertheless, the Federal Reserve banks continued to purchase government securities at a rate of approximately $\$ 50$ million per week until early July, when purchases were curtailed dramatically. Then, at its meeting on July 14, the OMPC authorized open market purchases of up to \$207 million, but indicated that "except in unusual or unforeseen circumstances purchases should not exceed 15 million dollars a week." ${ }^{9}$ By the statement week of July 30, 1932, open market purchases were effectively zero.

\footnotetext{
${ }^{6}$ Harrison Papers, "Meeting of Joint Conference of the Federal Reserve Board and the Open Market Policy Conference," April 12, 1932.

${ }^{7}$ Harrison Papers, "Minutes of the Meeting of the Joint Conference of the Federal Reserve Board and the Open Market Policy Conference," May 17, 1932.

${ }^{8}$ Harrison Papers, "Minutes of the Meeting of the Executive Committee of the Open Market Policy Conference," June 16, 1932. The prevailing level of excess reserves is given in the accompanying "Preliminary Memorandum for the Open Market Executive Committee," June 16, 1932.

${ }^{9}$ Harrison Papers, "Minutes of the Meeting of the Open Market Policy Conference," July 14, 1932.
} 


\section{B. Was the Public Aware of the Monetary Expansion?}

The rapid monetary expansion could have sparked devaluation fears only to the extent that the public was aware of the Federal Reserve's actions in the spring of 1932. The Federal Reserve did not always publicize its decisions, nor did it publicize the dates of the OMPC meetings. However, the Federal Reserve released its balance sheet every Thursday, and the balance sheet was published in the

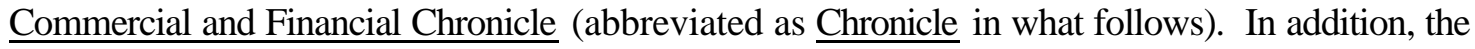
Chronicle had a weekly column that carefully scrutinized the balance sheet for information about the Federal Reserve's policies.

In addition to the information provided by the Federal Reserve's weekly balance sheet, the public sometimes learned of decisions taken by the OMPC through other channels. For example, several newspapers reported that the OMPC had met on January 11 and 12 and that some decision had been made during this meeting. The January 11 issue of the Journal of Commerce reported that "Governors of the Federal Reserve Banks, meeting in secret session as the Open Market Policy Committee of that System, considered the present situation and laid down a program for the half-year period." The article went on to say that "Among the economic proposals receiving much attention and one which probably was taken up at the meeting was that of a further easing of the credit situation, possibly through some type of inflation, by issuance of a greater volume of Federal Reserve notes."10 Based on an analysis of the Federal Reserve's balance sheet, the Chronicle (January 23, p. 548) noticed that any such decision to expand Federal Reserve credit had not been implemented.

There is no evidence that the public was aware of the OMPC's decision on February 24 and 25 to purchase approximately $\$ 25$ million of government securities per week. The lead articles in the Chronicle on February 13, 20, and 27 discussed the Congressional debate on and approval of the GlassSteagall bill, but did not mention the OMPC's meeting in February. Over the next six weeks

\footnotetext{
${ }^{10}$ Reprint of Journal of Commerce article in the Commercial and Financial Chronicle, Vol. 134, No. 3473, January 16, 1932, p. 430.
} 
(March 5 to April 9), the Chronicle's weekly column on the Federal Reserve's balance sheet noticed the weekly increase in the Federal Reserve's holdings of government securities, but focused on other aspects of its balance sheet.

The public first became aware of the OMPC's decision in February when Governor Harrison testified before Congress on April 13. During this appearance, Harrison also revealed the OMPC's decision the previous day (April 12) to accelerate the monetary expansion. Harrison's testimony was widely covered by in the newspapers. According to the lead article in the Chronicle on April 16 (p. 2774):

On Wednesday, April 13, Governor George L. Harrison ... appeared before the Goldsborough subcommittee of the House Banking Committee to discuss with it the question of stabilization legislation, and it was then revealed that the Federal Reserve System had embarked upon a new 'easy money' policy through open market purchases of Government securities at an accelerated speed, both as to rate and volume.

The New York Times stated: "By entering upon a policy of controlled credit expansion, designed to turn the deflation in bank credit and to stimulate a rise in prices, the Federal Reserve System has undertaken the boldest of all central bank efforts to combat the depression."11

The Federal Reserve's monetary expansion was the subject of the lead articles in the Chronicle over the next few weeks. These articles mostly focused on the information provided by the weekly balance sheets released by the Federal Reserve. The Chronicle commented frequently on the rapid pace and the extreme size of the monetary expansion. On April 23 (p. 2957), it wrote of the rate of purchases: "This is certainly going it fast." On April 30, the Chronicle (p. 3141) referred to the "Federal Reserve easy money policy, pursued with such diligence and on such an overwhelming scale." On May 21, the Chronicle reported that the OMPC had met on May 17 and that the Federal Reserve had released a statement that:

\footnotetext{
${ }^{11}$ New York Times quoted in the Commercial and Financial Chronicle, Vol. 134, No. 3486, April 16, 1932, p. 2774.
} 
The Governors of the Federal Reserve banks met to-day with the Federal Reserve Board, and it was decided to continue open market operations by the purchase of Government securities, the extent and amount to be determined from time to time as conditions justify. ${ }^{12}$

There is no evidence that the public was aware of the Federal Reserve's intention by mid-June to scale down its monetary expansion program. Because the Federal Reserve did not make any statement about the meeting of the OMPC on June 16, there was no mention of this meeting in any newspaper. Instead, on June 18, the Chronicle (p. 4368) wrote: "there has been no change whatever in Reserve policy with regard to the purchase of United States securities." Several articles in the

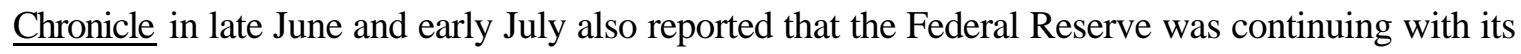
monetary expansion program. For example, on June 25 (p. 4531), it discussed the fact that the Federal Reserve Bank of New York had lowered its discount rate as "part of the easy money policy to which the Federal Reserve authorities have been so long committed." The same issue (p. 4533) also noted: "The Federal Reserve authorities continued their policy of purchasing United States Government securities." The following week (July 2), the Chronicle (p. 4) wrote: "The Reserve banks also continue to add to their holdings of United States Government securities, and the addition this week has been on a larger scale than that of last week."

From analyzing the Federal Reserve's balance sheet, the Chronicle noticed that open market purchases declined dramatically the next week. On July 9 (p. 169) it wrote: "Another point of interest is that there has been the present week no further acquisition of United States Government securities." It did not, however, act as though an obvious change in policy had occurred or that the decline in open market purchases was necessarily permanent. Indeed, the following week, the Chronicle (July 16, p. 339) noted: "the Federal Reserve authorities indulged in further purchases of Government securities." The Federal Reserve did not publicize the meeting of the OMPC on July 14 and the Chronicle

\footnotetext{
${ }^{12}$ Federal Reserve statement quoted in the Commercial and Financial Chronicle, Vol. 134, No. 3491, May 21, 1932, p. 3679.
} 
contained no mention of it. On July 23, the Chronicle (p. 504) wrote:

It is to be observed, however, that though the further acquisition of U.S. Government securities during the week has been relatively small, there has nevertheless been some increase and to that extent marks further advance in the wrong direction.... In other words the process of expansion still continues.

Thus, it appears that as late as mid-July, the public was not aware that the open market purchase program was effectively ended.

This review of public perceptions suggests that market participants were very aware of the open market purchase program of 1932 and considered it to be a dramatic break with previous Federal Reserve policy. The financial press reported the stream of purchases throughout the spring and showed no signs of anticipating its end. Indeed, even when open market purchases had effectively stopped in mid-July, the press did not report the end of the program.

\section{DATA ON FORWARD RATES}

\section{A. Motivation}

Eichengreen's argument about the likely effects of expansionary policy focuses on the credibility of the gold standard. In his story, expansionary open market operations would have led people to doubt the U.S. commitment to the gold standard. If such doubts had been severe enough, the United States could have experienced a catastrophic loss of gold and been forced off the gold standard. This possibility is formalized in the so-called "first generation" models of speculative attack due to Krugman (1979) and expanded in a large subsequent literature. In the Krugman model, the government attempts to maintain a fixed exchange rate while issuing domestic credit to finance an excessively expansionary fiscal policy. Eventually, when reserves fall below a crucial threshold level, a speculative attack occurs.

Obviously, no such full-fledged speculative attack occurred during the 1932 expansion. But it 
is certainly possible that the monetary expansion led to more moderate doubts about the U.S. commitment to the gold standard. If expansion led to a moderate loss of credibility, this would have shown up in a rise in market expectations of devaluation. This implication of monetary expansion is also contained in the first-generation speculative attack models. In Krugman's original deterministic formulation of the model, instantaneous devaluation expectations (and interest rate differentials) remain zero until the time of the attack. However, devaluation expectations measured far enough into the future to capture the speculative attack would show the deterioration. Furthermore, the assumption of the Krugman model that people have complete information over the central bank's actions and can perfectly forecast the time of the attack is highly unrealistic. In the stochastic version of this model by Flood and Garber (1984), expectations of devaluation gradually increase as fundamentals deteriorate due to the monetary expansion. This occurs because as fundamentals progressively deteriorate, both the probability that a new shock will lead to a collapse and the size of the ensuing depreciation increase.

Thus, a test of the hypothesis that the 1932 monetary expansion led to a loss of credibility involves looking for the predicted change in devaluation expectations. To examine such expectations of devaluation we use the relationship between forward exchange rates and spot rates. If the open market purchase program led to expectations of devaluation, the forward dollar exchange rates should have risen relative to spot rates during the program. The use of forward rates to measure expectations of devaluation is standard in studies of both modern and historical episodes. ${ }^{13}$ In deriving our measure of expected devaluation below, we follow the procedures described in this literature for separating expected movements due to mean reversion from expected movements due to a loss of credibility. We also supplement the analysis of exchange rates with an examination of cross-country interest rate differentials.

\footnotetext{
${ }^{13}$ See, for example, Flood and Garber (1984), Svensson (1993), Rose and Svensson (1994), and Eichengreen and Hsieh (1996).
} 


\section{B. Data}

The data on spot and forward exchange rates that we use come from Einzig (1937, Appendix I, pp. 449-481). Einzig's data show the spot exchange rate and the 3-month forward rate between various currencies and the British pound. The data are extracted from the weekly circular published by the Anglo-Portuguese Colonial and Overseas Bank, Ltd. The rates quoted are for the Saturday of each week. $^{14}$

The data in Einzig are for spot and forward exchange rates between various currencies and the British pound. We infer spot and forward rates between the dollar and various currencies by dividing the rate between the dollar and the pound by the rate between the relevant alternative currency and the pound. ${ }^{15}$ The particular currencies that we consider are the French franc, the Swiss franc, the Dutch guilder, and the Belgian belga. We choose these four currencies because we are interested in expectations of dollar devaluation caused by American open market operations. Therefore, we want to consider currencies of countries thought to be firmly wedded to gold in this period.

France, Switzerland, the Netherlands, and Belgium satisfy this criterion. Eichengreen (1992, p. 288) discusses the fact that countries that were home to international financial centers, specifically the Netherlands and Switzerland, felt it was crucial to maintain convertibility and stability. France and

\footnotetext{
${ }^{14}$ As a check on the accuracy of Einzig's data, we compared his figures for the dollar/pound spot rate with data from the Commercial and Financial Chronicle for the first six months of 1932. The Chronicle lists the bid and ask rates separately and quotes spreads for both cable transfers and banker's sight bills. This comparison confirms the accuracy of Einzig's data. Einzig's dollar/pound spot rates are always within the bid-ask spread for both cable transfers and banker's sight bills.

${ }^{15}$ Calculating the dollar/other currency spot and forward rates by taking the ratio of each currency to the pound may add measurement error to the exchange rate quotations. However, the size of this possible measurement error is constrained by the transaction costs. Since transactions costs in foreign exchange markets were low in the late 1920s and early 1930s, the measurement error should be small. Direct evidence on the size of the measurement error can be deduced by comparing our indirect quotations derived from Einzig with direct quotations from contemporary publications. We compare our indirect measure of the dollar/French franc spot rate for the first six months of 1932 with the rate given in the Commercial and Financial Chronicle. This comparison shows that our indirect observations are very close to the direct quotations. The difference is typically less than $1 / 10$ of one percent and never more than a few tenths of one percent.
} 
Belgium had also made it clear they were determined to remain on gold. Indeed, even as late as July 1933 these four countries (along with Italy) issued a joint declaration affirming their commitment to gold (Eichengreen, 1992, p. 337). For this reason, most movements in the spot and forward rates of the dollar relative to these currencies should reflect expectations about the American commitment to gold.

\section{Measure of Expected Devaluation}

Devaluation expectations can be deduced from the relative behavior of the forward rate and the spot rate. For example, if the dollar/franc 3-month forward rate rises for the same spot rate, investors are clearly expecting some devaluation of the dollar. The only complication involves mean reversion. Suppose that the current spot rate is temporarily low for some reason. In this case, the forward rate might be high relative to the spot rate, not because people doubt the U.S. commitment to the gold standard, but because the current spot rate is below the normal parity. ${ }^{16}$

To derive a measure of expected devaluation due to a loss of credibility, we first estimate typical mean reversion. To do this, we regress the difference between the spot rate three months (13 weeks) ahead and the current spot rate on a constant and the current spot rate. That is, we estimate:

$$
\mathrm{e}_{\mathrm{t}+13}^{\mathrm{spot}}-\mathrm{e}_{\mathrm{t}}^{\mathrm{spot}}=\alpha+\beta \mathrm{e}_{\mathrm{t}}^{\mathrm{spot}}+\varepsilon_{\mathrm{t}}
$$

where $\mathrm{e}^{\text {spot }}$ is the log of the spot exchange rate. We choose as our sample period January 1, 1927 to June 29, 1929. This two-and-a-half year period is close to the period of interest, but precedes the disruptions associated with the Great Depression. As a result, it reflects the behavior of spot rates during a period when the credibility of the gold standard was almost surely not in question. ${ }^{17}$

\footnotetext{
16 The importance of mean reversion and the "drift adjustment" that we use is discussed in Svensson (1993).

${ }^{17}$ We stop in June 1929 so that the spot rate three months ahead is still before the Great Crash of the U.S. stock market and other obvious events heralding the start of the Depression. We have also
} 
The results of this regression for the four dollar exchange rates we consider show substantial mean reversion. A coefficient of -1 would imply complete mean reversion within the next three months, while a coefficient of 0 would imply no mean reversion. Our estimates range from a low of -0.56 (for the dollar/belga rate) to a high of -0.91 (for the dollar/Swiss franc rate). The coefficients are estimated quite precisely; the t-statistics range from a low of -6.98 (for the dollar/belga rate) to a high of -10.95 (for the dollar/Swiss franc rate).

We use these estimates of mean reversion to construct a measure of expected devaluation due to a loss of credibility. In particular, our measure is the difference between the three-month forward rate and the spot rate, minus the predicted change in the spot rate due to mean reversion. This measure shows the expected devaluation over the next three months that cannot be attributed to mean reversion. We refer to this as net expected dollar devaluation (NEDD) because it is "net" of mean reversion. In symbols our measure is:

$$
\operatorname{NEDD}_{\mathrm{t}}=\left(\mathrm{e}_{\mathrm{t}}^{\text {forw }}-\mathrm{e}_{\mathrm{t}}^{\mathrm{spot}}\right)-\left(\hat{\alpha}+\hat{\beta} \mathrm{e}_{\mathrm{t}}^{\mathrm{spot}}\right)
$$

where $\mathrm{e}^{\text {forw }}$ is the $\log$ of the three-month forward exchange rate and $\mathrm{e}^{\text {spot }}$ is the log of the spot exchange rate. We multiply our measure by 100 to convert it to an expected percentage devaluation. We calculate this measure for the period June 1929 to March $1933 .{ }^{18}$

estimated mean reversion for the period January 1, 1927 to March 28, 1931. This period includes the years of the Depression before there were substantial movements in the spot exchange rates of major currencies. The results are quite similar to the shorter, more obviously credible, period.

${ }^{18}$ Our estimates of expected dollar devaluation net of mean reversion differ relatively little from a simple measure of expected devaluation (calculated as the difference in the logarithms of the forward rate and the spot rate, times 100). The correlation between the two series in the period October 3, 1931 to March 4, 1933 ranges from 0.79 for the dollar/Swiss franc exchange rate to 0.96 for the dollar/Belgian belga rate. In the spring of 1932, the net expected devaluation series show a slightly greater rise than the simple measures. This is because the spot rate between the dollar and the various gold-bloc currencies is somewhat above the level it tends to revert to; so mean reversion implies an appreciation of the dollar. 


\section{DEVALUATION EXPECTATIONS IN THE 1932 EXPERIMENT}

\section{A. Graphical Analysis}

Figure 1 graphs our measure of expected dollar devaluation net of mean reversion. The four panels show net expected dollar devaluation relative to the French franc, the Swiss franc, the Dutch guilder, and the Belgian belga. All four panels show net expected dollar devaluation starting in July 1931, when Britain began to have serious balance of payments problems, and ending in early March 1933, just before the American suspension of gold convertibility.

The vertical lines show the start and end of the open market purchase program. As described in Section I, the key decision to start the program occurred on April 12, 1932 and purchases began immediately. Thus, for our data, which are for Saturdays, the first exchange rate observation under the program was April 16, 1932. We therefore draw the first vertical line at April 9, 1932, the last observation before the program. The end date of the program is less clear-cut. There was a meeting on July 14 and 15, 1932 at which a decision was made to do little more, but there was no announcement to this effect and open market purchases did not fall immediately to zero. As a compromise we choose July 16, 1932 as the last Saturday exchange rate observation under the program. This is the date to which the second vertical line corresponds. ${ }^{19}$

One fact that is evident from Figure 1 is that net expected dollar devaluation varied little across the four currencies during the period 1931-1933. This suggests that it was expectations about the American commitment to the gold standard that were driving movements in the series, not questions about the foreign commitment. Put another way, our supposition that France, Switzerland, the Netherlands, and Belgium were viewed as firmly committed to gold in this period appears to be confirmed by the data. These four currencies were rarely expected to move relative to each other.

\footnotetext{
${ }^{19}$ Because our choice of an end data is inherently somewhat arbitrary, we have experimented with dates both a week earlier and a week later. None of our results are sensitive to the end date chosen.
} 
One exception to this general pattern involves the Netherlands at the end of 1931 . There was clearly a short period when the guilder was expected to depreciate relative to the other gold-bloc currencies.

A second fact that is evident from Figure 1 is that there was a slight rise in net expected dollar devaluation during the 1932 open market purchase program. The 3-month forward rate rose slightly relative to the spot rate (net of expected mean reversion) for all four of the dollar/gold-bloc currency combinations. However, the amount of expected dollar devaluation was small in all four cases. The maximum expected dollar devaluation during the 1932 experiment ranged from 1.38 percent, for the dollar relative to the belga, to 2.84 percent, for the dollar relative to the Swiss franc.

One way to put these values in context is to consider what they imply about the expected probability of a significant devaluation. In September 1931, Britain devalued by 26 percent relative to the dollar. We can use the expected devaluations graphed in Figure 1 to deduce how likely people thought it was that the United States would be forced to devalue by an amount equal to Britain's devaluation over the next three months. During the 1932 expansion, the implied maximum probabilities of a major U.S. devaluation were 6 percent based on the dollar/French franc evidence; 11 percent based on the dollar/Swiss franc evidence; 7 percent based on the dollar/guilder evidence; and 5 percent based on the dollar/belga evidence.

A third, and arguably the most important, fact that is evident from Figure 1 is that the expectations of dollar devaluation were far from constant during the 1932 open market purchase program. In all four cases expectations of dollar devaluation initially fell or remained constant for the first few weeks of the program. Expected dollar devaluation then rose toward the middle of the program, peaking in late May or early June. Finally, expected dollar devaluation dropped precipitously in June and early July. In all cases but one, the expected rate of dollar devaluation was substantially lower well before the end of the program than it was before the program started.

This variable behavior of devaluation expectations is crucially important because it does not correspond to either the actual pattern of open market purchases during the program or to news and 
expectations about what the Federal Reserve was doing. Figure 2 shows the weekly change in the Federal Reserve's holdings of U.S. government securities. ${ }^{20}$ Figure 2 makes clear that the program began with a bang. Open market purchases averaged roughly $\$ 100$ million per week for the first six weeks of the program (from April 16 to May 21). As described above, the start of the program was well known because Governor Harrison discussed the program in Congressional testimony the day after it was initiated. The Federal Reserve's actions were also discussed extensively in the press. Nevertheless, expectations of dollar devaluation were typically falling during the first month of the program.

Open market purchases slowed down in late May and then remained steady at the lower level for the next six weeks. Purchases averaged roughly $\$ 55$ million per week for the weeks between (and including) May 28 and July 2. The peaks in devaluation expectations thus do not correspond to obvious changes in Federal Reserve behavior. Devaluation expectations rose at a time when the Federal Reserve was, if anything, cutting back on the program. They then fell quite precipitously at a time when the Federal Reserve was holding purchases steady at a moderately expansionary level. Indeed, devaluation expectations had fallen below their initial level at least three weeks before open market purchases were seriously curtailed (which occurred during the week of July 9).

There is also no obvious news about the program that corresponds to the hump in expectations. As described in Section I, the program stopped making headlines in early May, and was mainly noted in business-like discussions of the Federal Reserve's balance sheet during late May and June. Thus, there was no news of expansion or acceleration of open market purchases that could explain the rise in devaluation expectations. Perhaps more importantly, there was also no news that can explain the drop

\footnotetext{
${ }^{20}$ The data are again from the Twentieth Annual Report of the Federal Reserve Board (1933, Table 4, pp. 78-89). The figures are for Wednesdays. For consistency with the exchange rate data (which are for Saturdays), we assign the change in the Federal Reserve's holding of government securities from Wednesday to Wednesday to the following Saturday. This corresponds quite well to the news value of the series because the Federal Reserve's balance sheet was published in the Commercial and Financial Chronicle each Saturday.
} 
in devaluation expectations in mid-June. It is most definitely not the case that people expected the program to end. The Federal Reserve was continuing to buy bonds and, as described above, we find no discussion that this was expected to change soon.

The bottom line of this simple graphical analysis is that net expected dollar devaluation did rise in late May and early June of 1932, but the change was very small. More importantly, the timing and pattern of this rise shows virtually no correlation with the open market purchase program. Expectations of devaluation fell with the well-publicized dramatic start of the program and rose when the program was continuing at a somewhat scaled-back pace. Expectations of dollar devaluation then fell significantly before there was any actual or anticipated change in Federal Reserve policy.

\section{B. Regression Analysis}

While the graphical analysis certainly suggests little correlation between the open market purchase program and expectations of devaluation, it is useful to test this conclusion formally. The obvious way to do this is to specify a dummy variable for the 14 weeks that the program was in effect and then regress our measure of net expected devaluation on this dummy variable and a constant. If the coefficient on the dummy variable is not statistically different from zero, this would indicate that the program had no effect on expectations that is distinguishable from random variation.

One complication, however, is the obvious serial correlation of the dependent variable. As Figure 1 shows, movements in our measure of net expected dollar devaluation are highly persistent. This suggests that there are unobserved serially correlated factors, such as political crises, business cycles, or animal spirits, that move devaluation expectations. As a result, if these factors are not controlled for, the residuals of the simple regression described above will be serially correlated. To deal with this serial correlation we include a lagged dependent variable in our regressions. ${ }^{21}$ That is,

\footnotetext{
${ }^{21}$ Alternatively, we could estimate the regressions with an AR-1 correction. Econometrically, the two procedures are almost equivalent.
} 
our specification is:

$$
\mathrm{NEDD}_{\mathrm{t}}=\gamma+\lambda \mathrm{NEDD}_{\mathrm{t}-1}+\rho \mathrm{DOMO}_{\mathrm{t}}+\varepsilon_{\mathrm{t}}
$$

where NEDD is net expected dollar devaluation relative to some currency and DOMO is the dummy variable for the 1932 open market purchase program. We are thus testing whether the 1932 open market purchase program had an effect on devaluation expectations beyond what can be explained by lagged expectations.

The dummy variable used in the regressions corresponds to that underlying the vertical lines in Figure 1. It is one in every week between (and including) April 16, 1932 and July 16, 1932. The sample period used for estimation is October 3, 1931 through March 4, 1933. We start after Britain's devaluation in September 1931, because this dramatic event may have ushered in a new era of exchange rate behavior. We stop just before the United States' suspension of convertibility in midMarch of $1933 .^{22}$ We run the regressions separately for expected dollar devaluation relative to each of the currencies considered.

The results are given in Table 1. The estimates confirm the impression given by the graphs: there is no correlation between net expected devaluation and the open market purchase program. The coefficient on the dummy variable is consistently very small in absolute terms and not statistically different from zero. Indeed, the t-statistics are all less than 1 in absolute value. The regressions also confirm the strong serial correlation of the net expected devaluation series: the coefficients on the lagged dependent variable are all in the vicinity of 0.8 and significantly different from zero at the 1 percent level. $^{23}$

\footnotetext{
${ }^{22}$ Starting the regressions in July 1929 (at the very start of the Great Depression and just after the credible period used to form our dependent variable) has no effect on the results.

${ }^{23}$ It could be appropriate to include lags of the dummy variable if one believes that for some reason foreign exchange markets were slow to respond to publicly available news about the open market
} 
One thing that is obvious from the graph in Figure 2 is that open market purchases were not constant during the 1932 expansion. As a result, specifying a simple dummy variable that is equal to 1 in all 14 weeks potentially obscures crucial variation in our explanatory variable. For this reason, we also try calibrating our dummy variable by the change in Federal Reserve holdings of government securities. Specifically, we multiply the dummy by open market purchases (in millions of dollars) in the corresponding week. ${ }^{24}$

Table 2 shows the results using the calibrated dummy variable. The estimates again confirm the intuition derived from the graphical analysis. The correlation between devaluation expectations and the open market purchase program is equally low when one accounts for the variation of open market purchases across different weeks of the program. The effects of the open market purchase program on expectations of devaluation are indistinguishable from zero, both economically and statistically.

\section{Devaluation Expectations in Other Episodes}

One concern with this analysis is that forward rates may not reveal expectations of devaluation that are nonetheless present. This could occur if the forward market were thin, or imperfect in some other sense. One way to check for such imperfections is to look at devaluation expectations derived from forward rate data in episodes when such expectations are widely thought to have been present.

Two such episodes are provided by the French experiences of 1934 and 1935. Eichengreen (1992, p. 355) describes how a political crisis in early February 1934 led to expectations of fiscal and monetary expansion. These expectations led to fears of devaluation and a large loss of gold in the first

purchase program. When we estimate equation (3) including the contemporaneous value and six lags of DOMO, neither the individual coefficients nor the sum of the coefficients are significantly different from zero for any of the four net expected dollar devaluation series.

${ }^{24}$ It would not be appropriate to simply include the entire time series of open market purchases in the regression. Open market purchases during the 1930s almost surely had an endogenous component; the Federal Reserve did at times move them in response to fears of devaluation. During the 1932 expansion, in contrast, the decision to expand had been made and the variation in open market purchases was related to factors other than devaluation expectations. Section IV discusses these other factors in detail. 
two weeks of February. In May of 1935 Belgium devalued. Eichengreen suggests that this, together with the fact that the French government was pursuing "New Deal style" expansionary monetary and fiscal policies, again led to fears of devaluation in May 1935 (1992, pp. 367-369).

Figure 3 shows the simple expected devaluation of the dollar relative to the French franc for the period 1929-1936. ${ }^{25}$ We use the dollar/franc rate in this comparison because after 1934, when the dollar is rebenchmarked to gold, movements in the dollar/franc series almost surely are driven primarily by expectations about the franc. This would not be true of the exchange rate between the French franc and other gold-bloc currencies such as the Swiss franc or the Belgium belga; there was great uncertainty about the stability of all these currencies. For consistency with earlier graphs we show expected dollar devaluation. A negative number is therefore expected devaluation of the franc.

Figure 3 indicates that both French episodes show up much more strongly in the data than does the 1932 American open market purchase program. In February 1934, expectations changed from an expected franc appreciation of $1 / 2$ percent to an expected franc devaluation of $1 \frac{1}{2}$ percent. For comparison, in the 1932 U.S. expansion, expectations changed only from an expected dollar devaluation of about $1 / 2$ percent to an expected dollar devaluation of 1 percent. While the overall level of expected franc devaluation was only about $1 \frac{1}{2}$ times as large in 1934 as the expected dollar devaluation in 1932, the change in the 1934 French episode was roughly four times as large as the change in the American episode. This same pattern holds even more strongly in the 1935 French episode. In May 1935, expected franc devaluation rose from $1 / 2$ percent to $61 / 4$ percent, and remained above 3 percent for several weeks. These episodes show that forward rates can provide evidence of devaluation expectations in the interwar period.

The American experience in early 1933 provides a different type of corroborating evidence.

\footnotetext{
${ }^{25}$ We use the simple expected devaluation series rather then the estimated net expected devaluation because the American devaluation of 1933-34 changed the level to which the dollar/franc exchange rate reverted. There is not a sufficiently long credible period after the dollar was fixed again to gold for us to estimate mean reversion.
} 
Because the United States suspended gold convertibility in March of 1933, it is often presumed that expectations of devaluation must have been rampant during this period. And yet, the simple expected dollar devaluation series (relative to the French franc) given in Figure 3 shows only a small rise in early 1933. Likewise, the net expected dollar devaluation series given in Figure 1 also show only a modest rise in devaluation fears through the end of February. Our reading of the narrative evidence suggests that this picture of devaluation expectations derived from forward rates is accurate, while the common presumption is not. $^{26}$

Perhaps the best evidence that devaluation fears were minimal in early 1933 is the fact that the gold price of the dollar remained constant for more than a month after the suspension of convertibility. Following emergency legislation surrounding the Bank Holiday, gold convertibility and gold exports were suspended by executive order on March 10, 1933. This left the dollar free to depreciate. However, according to Friedman and Schwartz (1963, p. 464), it was only after a further executive order and a speech by Roosevelt on April $20^{\text {th }}$ that made it clear he favored depreciation that the price of the dollar fell relative to the remaining gold-bloc currencies. If the dollar had been widely expected to depreciate in early 1933 , the fall in the price would have occurred as soon as convertibility was suspended.

A systematic reading of the Commercial and Financial Chronicle between November 1932 and April 1933 also shows that devaluation fears were minimal. Throughout December and early January, uncertainty about the U.S. commitment to the gold standard and the possibility of devaluation were not discussed. Instead, the Chronicle contained numerous mentions of the fact that "daily and weekly [Federal] Reserve statements show that gold is flowing into the country in a perfect stream" (January 7 , p. 3). In late January there was discussion of "the inflationary proposals that appear to be finding favor in the Lower House" (January 28, p. 531), but the Chronicle expressed confidence that the

\footnotetext{
${ }^{26}$ Wigmore (1987) provides several reasons why people might have expected devaluation of the dollar in early 1933, but little direct evidence that such expectations were actually present.
} 
Senate would prevent their passage. On February 25, the Chronicle (p. 1243) expressed concern that "another scare seems to have developed abroad as a result of these inflation propositions and a new eruption of banking troubles in various parts of the United States and withdrawals of gold for export and for earmarking on foreign account are again proceeding on a large scale." But, it went on to say (p. 1243): "Of course, the United States has enormous supplies of the metal." The Chronicle also reacted positively to Roosevelt's choice for Secretary of the Treasury. It said (p. 1242): "some having feared something of an upheaval, in the nature of a departure from sound economic principles and such fears it would appear may now be dismissed. That does not mean of course that there may not be a change of policy in several directions but does mean that dangerous ventures are unlikely." These quotations suggest that fear of inflation and devaluation was relatively small as late as the end of February. When the Bank Holiday and suspension of convertibility were declared in early March, the Chronicle saw some fears of devaluation, but suggested that they were short-lived. On March 11 (p. 1605), it wrote of the upward trend in European stock prices: "This tendency, like the recessions in the unofficial quotations on dollar exchange, was due to a very widespread fear that the banking crisis would be followed by inflation in the United States. Any lapse from the gold standard by this country, it was further reasoned, would seriously affect the few remaining gold standard countries." But the $\underline{\text { Chronicle }}$ (p. 1605) went on to say: "The advances in equities were not carried very far, owing to the assurances against inflation given by the new Administration in Washington and the vigorous steps for control of the banking crisis." Then on March 18, the Chronicle declared (p. 1755): "there has been a complete transformation in the outlook: Where previously there was doubt and despair, and where the future was viewed with a degree of anxiety bordering on alarm, there is now hopefulness amounting almost to enthusiasm, while confidence has replaced doubt and apprehension." These declarations of modest fears that were quickly resolved is consistent with the small, temporary rise in expected dollar devaluation shown by the forward rate data in the first two weeks of March. 


\section{Interest Rate Differentials}

Another way to check the results derived from forward exchange rates is to look at nominal interest rate differentials between the United States and the gold-bloc countries. A basic arbitrage condition implies that investors must be indifferent between buying a foreign bond today and buying an American bond of the same duration and quality together with a futures contract for conversion of the proceeds into the foreign currency at redemption. ${ }^{27}$ Thus, nominal interest rate differentials on similar assets provide another estimate of devaluation expectations. If American interest rates rose relative to foreign rates, we can deduce that investors' expectations of dollar devaluation over the life of the bond had risen. ${ }^{28}$

Interest rate data are available for the five countries examined from a variety of sources. Panel a of Figure 4 shows monthly data on the three-month private discount rate from Einzig (1937, Appendix III, pp. 491-498). The private discount rate is the rate at which private bills are traded on the open market; for the United States it is the rate on prime bankers' acceptances. Panel b shows monthly data on long-term government bond rates. For the United States, France, and Belgium, the rates are for tenyear bonds; for the Netherlands and Switzerland, the rates are for a mixture of bonds with durations exceeding ten years. ${ }^{29}$ In both panels, what is graphed for each country is the difference between the American rate and that country's rate. Both panels include vertical lines corresponding to the start and end of the 1932 open market purchase program.

For both short-term and long-term interest rates, the differentials between the U.S. and foreign rates were often substantial and persistent in the 1930s, indicating that the assets being analyzed are not

\footnotetext{
${ }^{27}$ Transactions costs can obviously place a small wedge between the returns from these two strategies. ${ }^{28}$ In making this comparison, one might wish to make the adjustment for mean reversion in the exchange rate discussed above. However, since the analysis in Section II shows that the drift adjustment is small and only strengthens our findings, we analyze the simpler, unadjusted interest rate differentials in what follows.

${ }^{29}$ The long-term interest rate data are from the Global Financial Data database. The particular series that we use are: IGUSA10D, IGFRA10D, IGBEL10D,_CGSHD, and_SBDYD.
} 
strictly comparable. However, for our purposes, what matters are the changes in the differentials, because these changes reflect changes in devaluation expectations. For short-term rates, the differentials uniformly fell with the start of the 1932 open market purchase program. This suggests that, if anything, fears of devaluation fell rather than rose when the Federal Reserve began to expand. The differentials with some countries rose slightly in the middle of the program, but in all cases, they began to fall again or level out before the end of the program. This pattern shows a reassuring correspondence with the expectations of devaluation implied by the forward exchange rate data: there is little evidence of devaluation expectations in the spring of 1932, and the movement in expectations bears little relationship to either actual or anticipated Federal Reserve actions.

The behavior of differentials for long-term interest rates is more varied across the four comparison countries than the behavior of short-run differentials. The only substantial change involved the differential between the U.S. and Belgian long-term rates, which fell persistently during the 1932 open market purchase program. For the other countries, the change in the differentials during the U.S. monetary expansion was small and followed no consistent pattern. This suggests that the expansion did not lead to an obvious or pervasive rise in expectations of devaluation. This finding is important because the long-term interest rate differentials capture expectations over a much longer horizon than is possible with the forward rate data. There is no sign that the Federal Reserve's actions in 1932 led to fears that the United States would devalue over the coming decade.

\section{NARRATIVE EVIDENCE ON DEVALUATION EXPECTATIONS}

\section{A. Was the Federal Reserve Concerned about a Speculative Attack on the Dollar?}

While the foreign exchange data provide little evidence that the monetary expansion heightened devaluation expectations, the fact remains that the open market operations were stopped after three 
months. This raises the possibility that the Federal Reserve may have stopped the monetary expansion because it was concerned about an incipient speculative attack on the dollar. There were also large gold outflows during the spring of 1932, primarily to France, Switzerland, the Netherlands, and Belgium, which could be evidence of a speculative attack on the dollar.

To check for this possibility, we examine narrative evidence on the beliefs and motivations of the Federal Reserve. Our key source is the papers of George L. Harrison, Governor of the Federal Reserve Bank of New York. The Harrison Papers contain the Minutes of the Open Market Policy Conference of which Harrison was the chairman, and the Memoranda of Meetings of the Board of Directors of the Federal Reserve Bank of New York. They also contain a plethora of office memos and correspondence to and from Harrison.

There is little evidence that the Federal Reserve was concerned about a speculative attack on the dollar during the monetary expansion. The narrative evidence shows clearly that the gold exports, which began in mid-May of 1932, were largely an orderly withdrawal of foreign balances by the Bank of France and other European central banks. ${ }^{30}$ These withdrawals were widely anticipated by the Federal Reserve and were not taken as a sign that the monetary expansion was leading to fears of devaluation or a speculative attack.

The case of the French repatriation provides clear evidence of both the motivation of the foreign central banks and the Federal Reserve's interpretation of the gold outflow. On January 15, Harrison thanked Governor Moret for informing him of the Bank of France's plan to withdraw its earmarked gold from the United States. ${ }^{31}$ A subsequent letter on March 9 from Moret to Harrison explained that "the monetary Law of June 25, 1928, implicitly imposed upon the Bank of France the obligation to liquidate its foreign assets." Moret went on to say:

\footnotetext{
${ }^{30}$ This key point is discussed in Bordo, Choudhri, and Schwartz (1999, p. 11).

${ }^{31}$ Harrison Papers, "Cable to Governor Moret, Bank de France," January 15, 1932.
} 
The monetary crisis which developed in Europe beginning with the Spring of 1931, and which finally ended in the suspension of the convertibility into gold of the pound sterling, confirmed my conviction that it would be advisable to return everywhere, as soon as possible, to the true gold standard. ${ }^{32}$

Harrison responded to Moret on April 3 by saying: "As you know, and as I have explained in the past to Mr. Farnier and Mr. Lacour-Gayet, we have felt for some time that it would be desirable rather than hurtful from the point of view of our position to have the Bank of France gradually repatriate its dollar balances." 33

In addition to having known about the intention of the European central banks to withdraw gold from the United States before the advent of the 1932 open market purchase program, the Federal Reserve expressed the view that the gold outflow was a reason to undertake monetary expansion. The minutes of the February meeting of the OMPC record that:

Governor Harrison further pointed out that the country's gold stock had been reduced by about $\$ 100,000,000$ in the first two months of the year, with no offsetting gains to the market, and that further gold losses at the rate of about $\$ 50,000,000$ a month were to be anticipated. The purchase of government securities would have the effect of offsetting this gold loss and preventing it from causing an increase in rediscounts. ${ }^{34}$

The Chronicle (April 30, p. 3142) reported that in a speech in late April to the annual luncheon of the Associated Press, Treasury Secretary Ogden Mills declared "that the Federal Reserve program of buying Government securities could be fully justified on the ground of replacing exported gold and hoarded currency." During the height of the gold withdrawals in early June, Harrison argued to his directors "that he thought it would be a mistake to let up on our program at this point, in view of the country's heavy gold losses during the past week."35 Even Governor McDougal of the Federal Reserve Bank of Chicago, generally a staunch opponent of the open market operations, approved of

\footnotetext{
${ }^{32}$ Both quotations are from the Harrison Papers, "Letter from the Governor of the Bank of France to Mr. George L. Harrison," March 9, 1932.

${ }^{33}$ Harrison Papers, "Letter from Harrison to Moret," April 3, 1932. Farnier and Lacour-Gayet were two officials of the Bank of France who visited the Federal Reserve Bank of New York in October 1931 to discuss the French central bank's plan to repatriate its assets in the United States.

${ }^{34}$ Harrison Papers, "Minutes of the Meeting of Governors," February 24 and 25, 1932.

${ }^{35}$ Harrison Papers, "Memorandum: Meeting of Board of Directors," June 2, 1932.
} 
their use to sterilize gold outflows. In a letter to Harrison on July 9, McDougal informed him that "While purchases by the System for the purpose of offsetting gold exports were probably justified, we believe that the additional purchases made were much too large."36

Further evidence that the Federal Reserve believed that it should sterilize the gold outflow is provided by its response to the end of the gold drain. The European central banks had withdrawn nearly all their assets held in the United States by the second week in June. In response, at the meeting of the OMPC Executive Committee on June 16, Governor Harrison suggested that "With the gold export movement reduced, it would probably be possible to maintain substantial excess reserves with smaller purchases than in the past.",37

In mid-June the Federal Reserve thought it possible that Britain might also repatriate some of its gold holdings in the United States. Once again, however, the Federal Reserve was sanguine about this development. At the June 16 meeting of the Board of Directors of the New York Federal Reserve Bank, Governor Harrison discussed the possibility in the context of a proposed reduction in the Bank's discount rate. Harrison showed no signs of fearing that the rate reduction would trigger an increase in British earmarking. He said that "A change in the rate would not have any effect ... on the position of dollar-sterling exchange, and ... the Bank of England concurred with this opinion.” Harrison's main concern appears to have been one of perceptions. He feared that if the British, by coincidence, happened to increase earmarking soon after the rate reduction it "would be most disturbing to the public." The minutes of the meeting report that "It would be too bad, he thought, to lose whatever psychological value a reduction in our rate might have because of such a development."38

Aside from the numerous discussions of the European repatriation of gold, the records of the

\footnotetext{
${ }^{36}$ Harrison Papers, "Letter from McDougal to Harrison," July 9, 1932.

${ }^{37}$ Harrison Papers, "Minutes of the Meeting of the Executive Committee of the Open Market Policy Conference," June 16, 1932.

${ }^{38}$ All three quotations are from the Harrison Papers, "Memorandum: Meeting of Board of Directors," June 16, 1932.
} 
Federal Reserve during the 1932 open market purchase program are almost shocking in their lack of discussion of the gold constraint more generally. The idea that the gold standard might prevent the Federal Reserve from pursuing an expansionary policy was only raised at 1 of 5 meetings of the Open Market Policy Conference between April and July of 1932, and at only 2 of 21 meetings of the Board of Directors of the Federal Reserve Bank of New York during the same time period. And in two of the three instances, concerns over the gold standard were quickly dismissed by Federal Reserve officials.

One mention of the gold-standard constraint occurred on April 12, at the meeting of the OMPC at which the open market purchase program was initiated. During the meeting, "Governor Calkins raised the question whether a policy of this sort would be followed by large foreign withdrawals of funds, and Governor Harrison replied that there might be some withdrawals but he did not believe these would be sufficient to prove embarrassing." 39 A second mention occurred at the meeting of the Federal Reserve Bank of New York's Board of Directors on June 30. This time, “Governor Harrison said that some people might argue that our policy had been responsible for the recent heavy outflow of gold, but we know that it was largely the repatriation of central bank balances which would have been withdrawn in any case." 40

At the meeting of the Board of Directors of the New York Federal Reserve Bank on April 21, the gold-standard constraint was discussed twice, once explicitly saying it was not a problem and once saying that it was. First, Harrison mentioned that the passage of the Glass-Steagall Act in February 1932 had been a crucial precondition for the open market purchase program. He pointed out that "our own ability to carry a vigorous open market policy to its ultimate conclusion would have been hampered by the technical restrictions upon the use of our gold reserves contained in the Federal Reserve Act before its recent amendment." Second, Eugene Meyer, Governor of the Federal Reserve

\footnotetext{
${ }^{39}$ Harrison Papers, "Meeting of the Joint Conference of the Federal Reserve Board and the Open Market Policy Conference," April 12, 1932.

${ }^{40}$ Harrison Papers, "Memorandum: Meeting of Board of Directors," June 30, 1932.
} 
Board, said:

[T] here are two chief obstacles to the success of our present credit policy:

1. The talk of inflation in this country and of our ability to stay on the gold standard which is prevalent here and abroad.

2. The reluctance of some of the Federal $[R]$ eserve banks to cooperate wholeheartedly in the program.

Meyer's concerns about the gold standard were not echoed or discussed by anyone else at the meeting.

Moreover, Meyer himself seemed to believe that these concerns mainly argued against lowering the discount rate, not in favor of ending the open market purchases. His argument was that "A reduction in rates now ... would lend support to the idea of a wild inflation" and that "we must be thinking of what we are going to do when our buying program has come to an end. That will be the time to reduce rates, when we have no other ammunition to use." ${ }^{41}$

A retrospective study of American monetary policy written by E.A. Goldenweiser, Director of the Division of Research and Statistics of the Board of Governors in the 1930s, confirms the Federal Reserve's lack of fear about gold losses and a speculative attack in 1932. Goldenweiser argues that early in the Depression gold reserves were often a genuine worry of the Federal Reserve. However, once the Glass-Steagall Act of 1932 was passed, the gold situation was no longer worrisome (1951, pp. 156-161). In discussing the 1932 open market purchase program, Goldenweiser writes: "a Federal Reserve Bank could be forced to suspend by an excessive gold drain, but no such drain was in prospect and the possibility of a suspension for such a reason was never contemplated" (1951, p. 161).

In summary, this narrative evidence suggests a very different view of the Federal Reserve than that suggested by proponents of the gold-standard hypothesis. During the 1932 expansion, the Federal Reserve understood the source of gold outflows and was not worried about a speculative attack. Indeed, the gold flows of May 1932 were taken as an indication that open market purchases should be

\footnotetext{
${ }^{41}$ All three quotations are from the Harrison Papers, "Memorandum: Meeting of Board of Directors," April 21, 1932.
} 
continued, not as a sign that the U.S. commitment to the gold standard was being brought into question by the expansion.

\section{B. Public Perceptions of the Credibility of the Gold Standard}

It is also useful to consider narrative evidence on public perceptions. Is there evidence in the financial and general press that the monetary expansion caused expectations of devaluation or fear of a speculative attack? The main source that we consider is the Commercial and Financial Chronicle, which was the preeminent financial news source of the time. The Chronicle is a particularly useful source because it also excerpted stories on financial issues from general papers, such as the New York Times.

During the first two weeks of the large open market operations, the $\underline{\text { Chronicle }}$ expressed concern that this policy had led to a loss of confidence in the dollar. For example, during the week that the OMPC launched the large monetary expansion, the Chronicle (April 16, p. 2775) said of the open market operations: "That there is menace in them, in the fears at least aroused abroad, appears in the resumption of gold exports." However, by the third week of the program, concerns over a potential devaluation had receded from the pages of the $\underline{\text { Chronicle. }}$. On May 7, the Chronicle once again discussed fears of a potential devaluation, but attributed them not to the current monetary expansion, but to the House's passage of the Goldsborough bill, which directed the Federal Reserve to use credit expansion to restore prices to their 1926 level. ${ }^{42}$ The Chronicle (May 7, p. 3327) went on to reassure its readers, saying: "Federal Reserve banks, however, are so strongly fortified with holdings of gold ... that the fear apprehended does not appear likely to come to pass unless Congress should become positively mad in its follies."

\footnotetext{
${ }^{42}$ Sumner (1997) also surveys the press for expectations of devaluation during the early 1930s. He finds some evidence of such expectations in the spring of 1932, but his news sources attribute them primarily to budget conflict and expansionary legislation (such as the Goldsborough Bill) before Congress at the time.
} 
When gold exports to Europe accelerated in late May and early June, the Chronicle (June 11, p. 4198) editorialized that these outflows were due to the "deep distrust of the performances in the United States - the Federal Reserve policy of large-scale purchases of United States Government securities and the various propositions finding favor or being urged in Congress involving expenditures of billions of dollars." At the same time, the $\underline{\text { Chronicle }}$ seems to be aware that the continued open market operations were motivated in part by a desire to sterilize the gold outflows. In describing the monetary expansion program on May 21, the Chronicle (p. 3680) said that "the process [of monetary expansion] therefore seems now to have become a regular one and apparently is to continue so long as the gold outflow continues." Thus, the Chronicle appeared to be unsure whether to attribute the gold flows to Federal Reserve policy or Federal Reserve policy to gold flows.

There is some evidence that the Federal Reserve was concerned that the repatriation of gold, when combined with uncertainty over the amount of the Bank of France's assets in the United States, might cause devaluation expectations. And, indeed, the hump in net expected dollar devaluation shown in Figure 1 corresponds to this period of French repatriation of gold. To dispel the uncertainty, Harrison sent Moret a telegram on June 9 asking him to "favorably consider the advisability of earmarking promptly and at one time all your remaining holdings of approximately $\$ 93,000,000$." Harrison said that:

I am now of the opinion that an immediate repatriation of the whole amount would be favorabl[y] received here and probably subject to less criticism or misunderstandings by the public than a continuation of earmarks at a rate of $\$ 25,000,000$ for another four weeks. This is especially true in view of the fact that there is now no public knowledge of the extent of your dollar position and $\mathrm{n}[\mathrm{o}]$ way of determining how long earmarking at the present rate will continue. ${ }^{43}$

After Moret agreed to Harrison's request, Harrison informed the Governors of the Federal Reserve Board that he would "let the newspaper men know informally that the earmarking of this gold for the Bank of France completes the repatriation of their holdings of dollars except for small working

\footnotetext{
${ }^{43}$ Harrison Papers, "Telegram from Harrison to Moret," June 9, 1932.
} 
balances." 44

The acceleration of the French withdrawal and Harrison's notification of the press appears to have had the desired effect on public expectations. On June 10, the New York Times reported that "the Bank of France seems to have ceased its sales of dollars on Thursday [June 9], and this sufficed to cause recovery in American exchange to a rate at which gold exports were no longer possible." It went on to say that:

Up to this time, the mere fact of a continuous drainage of gold from the American market is the factor which has given most encouragement to speculators for the fall in dollar exchange. But that means that if and when the outflow terminates, the only recourse of bears will be to cover. ${ }^{45}$

On June 15, the New York Times reported that "The sudden ending of the long, anxious strain involved in nine months of almost constant gold exports ... was celebrated in the foreign exchange market by the strongest bull movement in dollars witnessed in many weeks."46

The Chronicle of June 18 (p. 4365) similarly reported the completion of the French gold repatriation very favorably and said: "Great gratification was expressed over the announcement in financial circles.” However, when the Federal Reserve Bank of New York lowered the discount rate the following week, the Chronicle (June 25, p. 4531) expressed substantial skepticism. While it did not see any obvious effect on public expectations of devaluation, it believed that the continued expansion "is operating powerfully to disturb confidence in the existing monetary situation." It went on to say:

[T] hough the [gold] outflow appears now to have been checked, because virtually no foreign balances by European central banks remain here, it is impossible to convince the astute minds of banking authorities abroad that we are not engaged through our largescale purchases of United States securities in a policy of outright inflation, which always in the past, when practiced by others, has resulted in disaster in the end.

\footnotetext{
${ }^{44}$ Harrison Papers, "Letter to all Governors," June 13, 1932.

${ }^{45}$ Reprint of New York Times article from June 10, 1932 in the Commercial and Financial Chronicle, Vol. 134, No. 3495, June 18, 1932, p. 4411.

${ }^{46}$ Reprint of New York Times article from June 15,1932 in the Commercial and Financial Chronicle, Vol. 134, No. 3495, June 18, 1932, p. 4410.
} 
Thus, the Chronicle may have still feared devaluation, though it does not see such fear in others.

In interpreting the Chronicle's remarks, it is useful to keep in mind that the paper was deeply opposed to the monetary expansion on a variety of grounds. The paper's discussion of the Chicago banking panic of late June contains a useful summary of the Chronicle's mindset. It wrote (July 9, p.168) that "a right use of the facilities of the Federal Reserve banks [is] employing them in periods of emergency and then without restraint and with the utmost freedom." It then went on to contrast this use of Federal Reserve resources with "carrying out an easy money policy intended to promote a revival of trade." Of the latter policy the $\underline{\text { Chronicle }}$ wrote:

The policy finds an illustration in the large-scale purchases of United States Government securities, when there was neither need nor warrant nor justification for it. Such a policy, thus conducted, is rank inflation of Reserve credit, and full of menace. It has the effect of creating unnatural ease and leads to such absurdities and monstrosities as the purchase of acceptances by the Federal Reserve banks on the discount basis of only $1 \%$ per annum, not sufficient to cover overhead costs.

This last reference to interest rates is particularly interesting. It certainly sounds as though the Chronicle is deeply concerned about low nominal interest rates, even though deflation had been rampant for more than two years. Thus, when the paper talked about the policy "disturbing confidence," it may be talking less about fears of devaluation and much more about general unhappiness with the program for other (and, in retrospect, obviously spurious) reasons.

On net, this survey of Federal Reserve records and the financial press suggests that the 1932 open market purchase program did not lead to widespread expectations of devaluation. The Federal Reserve saw no signs that a speculative attack was developing and was remarkably sanguine about the gold outflow in May. The financial press expressed some fear of devaluation when the program was announced, but then remained quiet until the French repatriation of gold in May. However, even during the gold outflow, concern about devaluation does not appear to have been widespread or severe. And once the organized gold outflow ceased, most fears of devaluation ceased as well. 


\section{Why Did the Federal Reserve End the Monetary Expansion?}

If the Federal Reserve was not concerned about a speculative attack on the dollar, why did it cease its open market purchases after only three months of expansion? Friedman and Schwartz argue that the Federal Reserve accelerated the open market operations in early April due to Congressional pressure. In their interpretation, the Federal Reserve ended the program in early July because Congress adjourned for the summer. We agree with Friedman and Schwartz that the desire to forestall Congressional action was one of several motivations behind the Federal Reserve's decision to accelerate the monetary expansion program in early April. However, we disagree with their view that the adjournment of Congress for its summer recess was central to the Federal Reserve's decision to end the open market operations in early July. As described in Section I, the Federal Reserve was considering stopping by mid-June. More importantly, the Federal Reserve seemed quite aware that stopping just as Congress adjourned would create problems when Congress reconvened in the fall. Harrison told his directors on July 11 that:

Governor Meyer agreed as to the desirability of going ahead with the System open market program saying that, if for no other reason, it is politically impossible for us to stop at this particular time.... [I]f it were terminated just as Congress adjourned we would be crucified next winter. ${ }^{47}$

We believe that the Federal Reserve decided to slow the monetary expansion in mid-June because its model of monetary policy led it to believe that monetary conditions were already loose and that further purchases would be of little use. Political infighting between the regional banks, primarily between the Federal Reserve Bank of New York and the Federal Reserve Bank of Chicago, finally ended the program in July. As described below, variants of both of these arguments have been made by others. Our contribution is to take a fresh look at the narrative record and to provide additional evidence.

Federal Reserve officials in the 1930s focused on bank borrowing and excess bank reserves as

\footnotetext{
${ }^{47}$ Harrison Papers, "Memorandum: Meeting of Board of Directors," July 11, 1932.
} 
their main indicators of monetary ease or tightness. For example, on May 12, Harrison told the Board of the New York Federal Reserve Bank that "The best yardstick to use [for measuring the success of monetary policy] ... would be the figures of member bank reserves." Harrison also believed that the most the Federal Reserve could do to stimulate the economy was to lower bank borrowing and increase excess reserves. At the same meeting, Harrison expressed the opinion that "When the figures of member bank reserves are sufficiently high to produce adequate pressure upon the banks and to provide adequate credit for business as recovery sets in, we shall probably have done our part. If commercial banks can't or don't use the credit which we provide, that is another problem."48 This characteristic of Federal Reserve behavior in the interwar period has been analyzed extensively in a number of studies. Meltzer (1995), Wheelock (1990), and Wicker (1966) all argue that Federal Reserve officials consistently used excess reserves (and the related phenomenon of bank borrowing from the Federal Reserve) as their main indicator of monetary conditions in the 1920s and 1930s.

As discussed in Friedman and Schwartz (1963) and Meltzer (1995), these notions of monetary policy reflected the dominant "real bills" view of policy held by the Federal Reserve. Under this doctrine, the amount of credit provided by the Federal Reserve should reflect the demand for credit arising from productive (as opposed to speculative) commercial transactions. It was thought that large amounts of credit provided in response to something other than such "real bills" would be unlikely to stimulate production and could promote speculative activity. Therefore, as long as excess reserves were sufficient to meet changes in the demand for productive credit, additional excess reserves would be of little beneficial use, and, indeed, potentially harmful.

A corollary of this focus on excess reserve and real bills was the belief held by many Federal Reserve officials that the best time to expand was when confidence was high or at least improving. For example, in reviewing the origin of the open market purchase program on June 30, Harrison said: "It was thought best, however, not to use our ammunition until the chances of effective response from the

\footnotetext{
${ }^{48}$ Harrison Papers, "Memorandum: Meeting of Board of Directors,” May 12, 1932.
} 
banking and business community would favor the success of our undertaking.," ${ }^{49}$ Many Federal Reserve officials believed that it only made sense to increase open market purchases if banks were likely to use the additional reserves to expand loans. As a result, contrary to the modern view of the role of a central bank, some Federal Reserve officials believed that it was best not to respond to a panic, but to wait until the crisis had passed before expanding.

This model of the economy hastened the end of the 1932 open market purchase program in two ways. First, in late May and early June, some Federal Reserve officials believed that the program had already worked. On May 26, Harrison told his directors that:

[E]xcess reserves of member banks are now at about the point where it had been thought they should be maintained. Purchases during the coming week, therefore, should be sufficient merely to offset gold exports, month-end and holiday currency needs, and other factors of demand for Reserve bank credit. ${ }^{50}$

Goldenweiser (1951, pp. 161-162) says that "Federal Reserve authorities felt that their monetary policy had made bank credit expansion possible and that they were powerless to induce banks to lend more freely or even to arrest loan liquidation." Consequently, meeting on June 16, the Executive Committee of the OMPC decided to scale down its open market purchases. In reviewing the open market operations with his directors on June 30, Harrison reiterated the view that the program had already been successful. He said that:

The program was launched and, at least up to the middle of June, achieved a considerable measure of success. Bank failures continued greatly reduced in number, currency hoarding practically ceased and there was some return flow of currency to the banks, bank loans and investments which previously had been declining at a perilous rate, were largely maintained and the whole grinding spiral of deflation was checked. ${ }^{51}$

The second way that the Federal Reserve's model of monetary policy hastened the end of the monetary expansion was by making some Federal Reserve officials believe that further purchases would be useless. In late June, a wave of banking panics in Chicago led Federal Reserve officials to

\footnotetext{
${ }^{49}$ Harrison Papers, "Memorandum: Meeting of Board of Directors," June 30, 1932.

${ }^{50}$ Harrison Papers, "Memorandum: Meeting of Board of Directors," May 26, 1932.

${ }^{51}$ Harrison Papers, "Memorandum: Meeting of Board of Directors," June 30, 1932.
} 
fear that widespread banking difficulties were about to begin. At the meetings of the Board of

Directors of the New York Federal Reserve Bank in early July, there were extensive discussions of possible bank closings and much criticism of the Reconstruction Finance Corporation for failing to prevent such closures. The unsettled banking situation led at least some members of the New York Board to feel that further open market purchases would have no impact. Harrison, for example, said that:

There is no sense ... in our purchasing Government securities merely as an offset to currency hoarding. That is an impossible task and an inversion of our program, which was based on a revival of confidence in the banking and credit structure. Unless we can get the Reconstruction Finance Corporation to liberalize its operations so as to check further bank closings ... it is doubtful whether we should pursue our open market program further. ${ }^{52}$

Thus, the Federal Reserve's model may have led some to abandon the program in July because they thought the preconditions for success were no longer met. ${ }^{53}$

A second reason for the end of the program was conflict among the 12 regional Federal Reserve banks. ${ }^{54}$ In early June, W. R. Burgess, deputy governor of the Federal Reserve Bank of New York "said that he thought some increase in our purchases would be desirable, but that we must remember that we have partners in this undertaking and that some of them are reluctant to go ahead." 55 By mid-June, the Federal Reserve Bank of New York was clearly unhappy about the fact that "the New York bank had found it necessary to absorb a considerably larger amount of governments than its own share." 56 Then, at the end of June, after the outbreak of a banking panic in Chicago, the Federal

\footnotetext{
${ }^{52}$ Harrison Papers, “Memorandum: Meeting of Board of Directors," July 7, 1932.

${ }^{53}$ This view was not shared by all members of the New York Board of Directors. Owen Young, for example, expressed the view on July 7 that "If the Federal [R]eserve banks have to abandon their open market program now ... it will be a fearful blow to the psychology of recovery. If there was ever a time that the banking situation should be held together, it is this month" (Harrison Papers, "Memorandum: Meeting of Board of Directors," July 7, 1932).

${ }^{54}$ This point is also made by Meltzer (1995).

${ }^{55}$ Harrison Papers, "Memorandum: Meeting of Board of Directors," June 9, 1932.

${ }^{56}$ Harrison Papers, "Minutes of the Meeting of the Executive Committee of the Open Market Policy Conference," June 16, 1932.
} 
Reserve Bank of Chicago refused to continue participating in the open market purchase program. The Federal Reserve Banks of Boston and Philadelphia followed the Chicago Bank's lead and also withdrew from the program.

Why the Chicago Federal Reserve Bank chose to drop out of the program when it did is a matter of some debate. ${ }^{57}$ Harrison told his directors on June 23 "that Governor McDougal, always a reluctant follower of the System program, is now more reluctant than ever to participate heavily in purchases of Government securities because of the demands which may be made upon his bank as a result of the recent closing of a number of small banks in Chicago." ${ }^{, 58}$ There is some evidence that the Chicago Board of Directors subscribed to the view that banking panics made further increases in reserves useless. Owen D. Young, deputy chairman of the Board of Directors of the New York Federal Reserve Bank, talked to several of the Chicago directors. He reported that:

[T]hey say what is the use of going ahead if bank failures are to continue and hoarding of currency to be renewed. In these circumstances they hold it to be futile to talk of the pressure of excess reserves upon member banks because, either there won't be any excess reserves or the banks will prefer the cost of carrying them to their use. ${ }^{59}$

Governor McDougal of Chicago cited as his reason for abandoning the program the notion that:

[P] urchases made were much too large and have resulted in creating abnormally low rates for short-term U.S. Government securities... [T] hese rates are abnormally low and have been artificially created by pouring a large excess of funds into the market which it does not need. ${ }^{60}$

As discussed by Epstein and Ferguson (1984), the refusal of the Federal Reserve Bank of Chicago to participate in the purchase program ultimately led to its abandonment. On June 23,

\footnotetext{
${ }^{57}$ Epstein and Ferguson (1984) argue that the Federal Reserve Bank of Chicago withdrew from the open market purchase plan because the monetary expansion was adversely affecting Chicago banks. They suggest that because banks in Chicago held large quantities of short-term government securities, their profits came under pressure when the open market operations drove returns on government securities to low levels. The Chicago Federal Reserve Bank thus opposed the open market operations to protect the profits of these banks. This story of regulatory capture has been disputed by Coelho and Santoni (1991).

${ }^{58}$ Harrison Papers, "Memorandum: Meeting of Board of Directors," June 23, 1932.

${ }^{59}$ Harrison Papers, "Memorandum: Meeting of Board of Directors," July 14, 1932.

${ }^{60}$ Harrison Papers, "Letter from McDougal to Harrison," July 9, 1932.
} 
Harrison "expressed some doubt as to whether the Federal Reserve Bank of New York should continue to bear the brunt of the burden of the System open market program, while the Chicago bank not only does not desire to take over some of the past purchases of Government securities for System account, but expresses reluctance to continue its participation in current purchases." Harrison thought that: "If there was ever a time when the Federal Reserve Bank of Chicago should do its part, ... it is a time such as the present when banking difficulties in Chicago are likely to result in demands upon New York for funds." Harrison also argued that with the reserve ratio of the New York Federal Reserve Bank at 50 percent and that of the Chicago Federal Reserve Bank at 75 percent, "it is difficult to see why we should pump funds into the market which will then be siphoned off to Chicago."61

On July 5, Harrison informed his directors that the Chicago, Philadelphia, and Boston Federal Reserve Banks were reluctant to continue the open market operations. He concluded that "if the other large Federal Reserve banks are unwilling to proceed with the program, we cannot carry the burden for the entire System, while our reserve percentage is the lowest of any bank in the System." Owen Young added that "if we cannot have the continuous participation of the Federal Reserve Banks of Boston and Chicago in the System program, I am for suspending the program." 62

The conflict between the Chicago and the New York Federal Reserve Banks that ultimately ended the monetary expansion program reflected deeper structural problems of the Federal Reserve System during this period. ${ }^{63}$ The Federal Reserve System had been purposefully set up as a decentralized system of twelve relatively autonomous central banks. Each bank had to back its note issues with eligible assets. Consequently, each Federal Reserve bank paid attention to its own reserves, and not to system-wide reserves. For example, on June 23, Harrison complained to his

\footnotetext{
${ }^{61}$ All three quotations are from the Harrison Papers, "Memorandum: Meeting of Board of Directors," June 23, 1932.

${ }^{62}$ Both quotations are from the Harrison Papers, "Memorandum: Meeting of Executive Committee," July $5,1932$.

63 This structural flaw is discussed extensively by Friedman and Schwartz (1963) in other contexts, but is not stressed in the discussion of the abandonment of the 1932 open market purchase program.
} 
directors that the New York Federal Reserve Bank had shouldered most of the burden of the open market operations and that "it is just as important for this bank to watch its reserve position as for any bank in the System." 64

In addition, until the Banking Act of 1933 was passed, each Federal Reserve bank could undertake its own open market operations. The OMPC had been established in 1930 as the successor of the Open Market Investment Committee to coordinate the activities of the twelve banks; but each bank could refuse to participate in the decision taken by the Conference. ${ }^{65}$ As a result, even during the few times when it was absolutely clear to the majority of the Federal Reserve's governors that expansionary monetary policy was urgently needed, such as the spring of 1932 , the decentralization of monetary policy resulted in policy paralysis. As Owen Young cogently summarized, under the institutional framework of 1932, "you may have two or three banks dictating the policy of the System at a critical time, just because of their ability to block a System program." 66

\section{IMPLICATIONS}

This paper has addressed a narrow question: Did the 1932 monetary expansion cause expectations of devaluation? Our answer is no. Forward rate data show a small rise in expectations of devaluation in the spring of 1932, but this rise is uncorrelated with either the Federal Reserve's actions or available news about the Federal Reserve's intentions. Devaluation expectations rose well after the dramatic initiation of the open market purchase program and fell to below their initial level more than a

\footnotetext{
${ }^{64}$ Harrison Papers, "Memorandum: Meeting of Board of Directors," June 23, 1932.

${ }^{65}$ For example, during a meeting of the New York Federal Reserve Bank Board of Directors on July 5, Mr. Reyburn, a Director of the New York Bank, "pointed out that the system Open Market Policy Conference is an extra legal body and that in its operation all of the Federal [R]eserve banks have reserved the right not to participate in its policies whenever they see fit to reject such participation" (Harrison Papers, "Memorandum: Meeting of Executive Committee," July 5, 1932).

${ }^{66}$ Harrison Papers, "Memorandum: Meeting of Board of Directors," July 14, 1932.
} 
month before the program ended. And both short-term and long-term interest rates differentials between the United States and key gold-bloc countries show virtually no change as a result of the 1932 monetary expansion.

This absence of devaluation expectations is confirmed by the narrative evidence. The records of the Federal Reserve show that it was not concerned that a speculative attack might occur. It understood that gold flows in mid-May were due to a widely anticipated European repatriation of foreign balances. Indeed, the Federal Reserve took the gold outflows as evidence that open market purchases should be continued, not curtailed. The financial press worried initially that the monetary expansion would lead to a speculative attack, but became quite calm by mid-June.

It is natural to ask whether these findings have broader implications for our understanding of the Great Depression. Do they imply that the Federal Reserve could have done more in 1932 to end the real decline without calling the U.S. commitment to the gold standard into question? Do they imply that the Federal Reserve could have done more in 1930 and 1931? Can they provide insight into why the Federal Reserve did not act to stem the cataclysm? Our answer to all three of these questions is yes.

\section{A. Could the Federal Reserve Have Done More in 1932?}

Our results suggest quite strongly that the Federal Reserve could have gone further in 1932. There is no sign that the monetary expansion was causing investors to doubt the U.S. commitment to the gold standard. If anything, fears of devaluation seem to have lessened as the program continued. Given that markets seemed quite reconciled to the expansion, there is every reason to think it could have continued for a substantial length of time.

Furthermore, there is reason to believe that further monetary expansion could have had beneficial effects on output. It is sometimes easy to forget that the United States recovered quite strongly in the summer and fall of 1932. Figure 5 shows that the Federal Reserve index of industrial 
production stopped falling in July 1932 and rose 12 percent between July and September of $1932 .{ }^{67}$

While coincident timing is obviously not proof of a causal relationship, it is suggestive.

There is also a plausible mechanism by which the monetary expansion may have had real effects: through lowering the real interest rate in the United States. As discussed above, adherence to the gold standard required that nominal interest rates on similar assets be equalized across participating countries. However, real interest rates could and did differ across gold-standard countries during the interwar era. Frictions in the world economy allowed deviations from purchasing power parity to be both substantial and persistent.

Following the 1932 open market purchase program, prices in the United States stopped falling and actually rose markedly in the summer of 1932. The Bureau of Labor Statistics (BLS) producer price index rose 2.1 percent between June and September of $1932 .{ }^{68}$ This fact, combined with the fact that nominal interest rates declined slightly, implies that ex post real rates fell following the monetary expansion. Figure 6 shows monthly observations on the ex post real rate based on the nominal rate on 90-day bankers' acceptances and the BLS producer price index. ${ }^{69}$ Figure 6 also shows two estimates of the ex ante real rate: one derived from a rolling autoregressive model of inflation expectation formation and the other from a Mishkin-type procedure. ${ }^{70}$ Real rates clearly fell quite sharply in mid1932.

${ }^{67}$ The Federal Reserve Board index of industrial production is from the Board of Governor's website. We use series B50001, which is seasonally adjusted and on a 1992 base.

${ }^{68}$ The produce price index is from the Bureau of Labor Statistics (1986).

${ }^{69}$ The nominal interest rate is from Einzig (1937, Appendix III, pp. 491-498). The ex post real rate is calculated by first converting the interest rate to the continuously compounded equivalent and then measuring inflation over the next three months as the difference in logarithms at an annual rate.

${ }^{70}$ The methods and data used to construct these estimates of the ex ante real rate are discussed in detail in Romer (1992). Briefly, the rolling autoregressive model regresses inflation over the next three months on current and six lags of inflation and monthly dummy variables and then forecasts the dependent variable one month ahead. The sample period always begins in 1923:1. The Mishkin procedure regresses the ex post real interest rate on monthly dummy variables and current and four lags of M1 growth, inflation, the nominal interest rate on 90-day bankers' acceptances, and the growth rate of industrial production. It then takes fitted values as estimates of the ex ante real rate. The sample period used is $1923: 1$ to $1933: 2$. 
The fact that actual and expected inflation rose following the 1932 open market purchase program is not inconsistent with our finding that the program had little effect on expectations of devaluation. Figure 7 shows the retail price of food in the United States and in the four gold-bloc countries being used for comparison. ${ }^{71}$ This figure shows that prices fell more severely in 1930 and 1931 in the United States than in the four European countries. Market participants could therefore have very plausibly believed that prices could rise more in the United States than abroad in 1932 without any threat to the gold standard.

\section{B. Could the Federal Reserve Have Done More in 1930 and 1931 ?}

Whether the lack of devaluation expectations in 1932 suggests that the Federal Reserve could have done more in 1930 and 1931 is a more difficult question. The Federal Reserve certainly seemed to think that the Glass-Steagall Act of 1932, which allowed government securities to serve as partial backing for Federal Reserve notes, was an important change. Whether the Federal Reserve was seriously constrained by its gold reserves before Glass-Steagall is outside the scope of this paper. But our results certainly suggest is that if Glass-Steagall had been in place in 1930 and 1931, the Federal Reserve could have expanded without setting off a speculative attack or expectations of devaluation. Thus, at the very least, the United States — that is, Congress and the Federal Reserve together could have expanded significantly without calling the American commitment to the gold standard into question.

In addition, it is quite possible that monetary expansion would have generated even fewer questions about the U.S. commitment to the gold standard in 1930 and early 1931 than it did in 1932.

\footnotetext{
${ }^{71}$ We consider the retail price of food because this is the price series most likely to be consistent across all five countries. Broader indexes, such as the composite wholesale price index, vary dramatically in scope, stage of processing, and detail across the five countries. For example, the U.S. wholesale price index for the interwar period includes 784 commodities while the conventional comparison series for France includes just 126 commodities and that for the Netherlands just 48 commodities. The retail food price series for all five countries is from the Bureau of Labor Statistics (1933, pp. 11-13).
} 
The British devaluation of September 1931 surely made markets much less confident of everyone's attachment to the gold standard than they had been before. In 1930 and early 1931, markets would almost surely have been quite confident that the Federal Reserve would not expand more than it could do comfortably within the gold-standard constraint.

The U.S. experience after the stock market crash of October 1929 provides some confirmation of this view. In November and December, the Federal Reserve actually expanded quite dramatically. Indeed, open market purchases were \$397 million between November 2 and December 21. Figure 8 shows that this short-lived expansion had virtually no effect on expectations of devaluation. The figure shows the longer time series of our measure of net expected dollar devaluation against the French franc derived in Section II. The measure is essentially constant throughout the last two months of 1929 and the first months of 1930. The same is true for expected dollar devaluation against the other currencies we consider. Thus, there is every reason to believe that further expansion would have been tolerated at least as well in 1930 and early 1931 as it was in 1932.

All of this suggests that the most that stood between the Federal Reserve and further expansion early in the Depression was a fairly straightforward legislative change. If the Federal Reserve had wanted to expand in 1930 and 1931, it need only have lobbied for the right to back some fraction of its notes with government securities. It did not need to be concerned that expansion would lead to serious concern over the U.S. commitment to gold.

\section{Why Didn't the Federal Reserve Act?}

Our study provides insight into why the Federal Reserve did not lobby for such legislation. We find that the Federal Reserve stopped the 1932 open market purchase program because it thought it had done enough. The Federal Reserve's misguided emphasis on excess reserves led it to think that it had succeeded in bringing about monetary ease and that further open market purchases would be useless. The diffuse power structure of the Federal Reserve System then sealed the fate of the 
expansionary program. Because the Board could not force the individual banks to purchase securities, a few dissenters managed to bring the majority to heel.

Based on what we observe in 1932, it is likely that the same misguided model and diffuse power structure prevented Federal Reserve action earlier in the Depression. The tendency of excess reserves to rise when the banking system was under stress quite possibly led Federal Reserve officials to misinterpret the stance of monetary policy during the financial panics of 1930 and 1931. And, since the key opponents of monetary expansion in 1932 held the same positions and beliefs in the first two years of the Depression, it is likely that the diffuse power structure of the Federal Reserve allowed them to block concerted action. Thus, throughout the early 1930s, the Federal Reserve was constrained not by fear of speculative attacks, but by ignorance and poor institutional design. 


\section{$\underline{\text { References }}$}

Bernanke, Ben S. "The World on a Cross of Gold: A Review of 'Golden Fetters: The Gold Standard and the Great Depression, 1919-1939'.” Journal of Monetary Economics 31 (April 1993): 251267.

Bernanke, Ben S. "The Macroeconomics of the Great Depression: A Comparative Approach." Journal of Money, Credit, and Banking 27 (February 1995): 1-28.

Bordo, Michael, Ehsan Choudhri, and Anna J. Schwartz. "Was Expansionary Monetary Policy Feasible During the Great Contraction? An Examination of the Gold Standard Constraint." NBER Working Paper 7125, May 1999.

Coelho, Philip R. P., and G. J. Santoni. "Regulatory Capture and the Monetary Contraction of 1932: A Comment on Epstein and Ferguson." Journal of Economic History 51 (March 1991): 182-189.

Eichengreen, Barry. Golden Fetters: The Gold Standard and the Great Depression, 1919-1939. New York: Oxford University Press, 1992.

Eichengreen, Barry, and Chang-Tai Hsieh. "Sterling in Decline Again: The 1931 and 1992 Crises Compared." In European Economic Integration as a Challenge to Industry and Government, edited by Richard Tilly and Paul Welfens. New York and Berlin: Springer-Verlag, 1996, pp. 355-385.

Einzig, Paul. The Theory of Forward Exchange. London: Macmillan, 1937.

Epstein, Gerald, and Thomas Ferguson. "Monetary Policy, Loan Liquidation, and Industrial Conflict: The Federal Reserve and the Open Market Operations of 1932." Journal of Economic History 64 (Dec. 1984): 957-983.

Flood, Robert P., and Peter M. Garber. "Collapsing Exchange Rate Regimes: Some Linear Examples." Journal of International Economics 17 (August 1984): 1-13.

Friedman, Milton, and Anna J. Schwartz. A Monetary History of the United States, 1867-1960. Princeton: Princeton University Press, 1963.

Goldenweiser, E. A. American Monetary Policy. New York: McGraw-Hill, 1951.

Krugman, Paul R. "A Model of Balance of Payments Crises.” Journal of Money, Credit, and Banking 11 (August 1979): 311-325.

Meltzer, Allan. "Why Did Monetary Policy Fail in the 1930s?" Chapter 5 of A History of the Federal Reserve. Unpublished manuscript, Carnegie Mellon University, 1995.

Romer, Christina D. "What Ended the Great Depression?” Journal of Economic History 52 (December 1992): 757-784.

Rose, Andrew K., and Lars E. O. Svensson. "European Exchange Rate Credibility before the Fall." European Economic Review 38 (May 1994): 1185-1216. 
Sumner, Scott. "News, Financial Markets, and the Collapse of the Gold Standard: 1931-1932." Research in Economic History 17 (1997): 39-84.

Svensson, Lars E. O. "Assessing Target Zone Credibility: Mean Reversion and Devaluation Expectations in the ERM, 1979-1992.” European Economic Review 37 (May 1993): 763-793.

Temin, Peter. Lessons from the Great Depression. Cambridge: MIT Press, 1989.

U.S. Bureau of Labor Statistics. Retail Prices. Washington, D.C.: U.S. Government Printing Office, August 1933.

U.S. Bureau of Labor Statistics. Historical Data on the Producer Price Index. Microfiche, 1986.

U.S. Federal Reserve Board. Twentieth Annual Report of the Federal Reserve Board. Washington, D.C.: U.S. Government Printing Office, 1934.

Wheelock, David. "Member Bank Borrowing and the Fed's Contractionary Monetary Policy during the Great Depression." Journal of Money, Credit, and Banking 22 (November 1990): 409-426.

Wicker, Elmus. "Federal Reserve Monetary Policy, 1922-33: A Reinterpretation.” Journal of Political Economy 73 (August 1965): 325-343.

Wigmore, Barrie A. "Was the Bank Holiday of 1933 Caused by a Run on the Dollar?" Journal of Economic History 47 (September 1987): 739-755. 
Table 1

Estimated Relationship Between $\mathrm{N}$ et Expected D ollar D evaluation and the 19320 pen M arket Purchase Program

(Simple Dummy V ariable)

\begin{tabular}{|c|c|c|c|c|}
\hline D ependent $V$ ariable & Constant & $\begin{array}{l}\text { Lagged Expected } \\
\text { Devaluation }\end{array}$ & $\begin{array}{l}\text { Dummy V ariable } \\
\text { for Program }\end{array}$ & $\mathrm{R}^{2}$ \\
\hline & \multicolumn{4}{|c|}{ (t-statistics are in parentheses) } \\
\hline $\begin{array}{l}\text { N et Expected D ollar } \\
\text { D evaluation R elative } \\
\text { to the F rench F ranc }\end{array}$ & $\begin{array}{c}0.11 \\
(2.01)\end{array}$ & $\begin{array}{c}0.84 \\
(11.20)\end{array}$ & $\begin{array}{l}-0.03 \\
(-0.27)\end{array}$ & 0.66 \\
\hline $\begin{array}{l}\text { N et Expected Dollar } \\
\text { D evaluation R elative } \\
\text { to the Swiss Franc }\end{array}$ & $\begin{array}{l}0.18 \\
(1.90)\end{array}$ & $\begin{array}{c}0.85 \\
(12.56)\end{array}$ & $\begin{array}{l}0.06 \\
(0.46)\end{array}$ & 0.74 \\
\hline $\begin{array}{l}\text { N et Expected D ollar } \\
\text { D evaluation R elative } \\
\text { to the } D \text { utch Guilder }\end{array}$ & $\begin{array}{l}0.08 \\
(1.46)\end{array}$ & $\begin{array}{c}0.81 \\
(9.40)\end{array}$ & $\begin{array}{l}0.05 \\
(0.37)\end{array}$ & 0.64 \\
\hline $\begin{array}{l}\text { N et Expected Dollar } \\
\text { D evaluation R elative } \\
\text { to the Belgian Belga }\end{array}$ & $\begin{array}{c}0.01 \\
(0.15)\end{array}$ & $\begin{array}{c}0.88 \\
(13.51)\end{array}$ & $\begin{array}{c}0.02 \\
(0.12)\end{array}$ & 0.77 \\
\hline
\end{tabular}


Table 2

Estimated Relationship Between N et Expected Dollar Devaluation and the 1932 O pen M arket Purchase Program

(Calibrated Dummy V ariable)

\begin{tabular}{|c|c|c|c|c|}
\hline D ependent $V$ ariable & Constant & $\begin{array}{l}\text { Lagged Expected } \\
\text { Devaluation }\end{array}$ & $\begin{array}{l}\text { Dummy V ariable } \\
\text { for Program }\end{array}$ & $\mathrm{R}^{2}$ \\
\hline & \multicolumn{4}{|c|}{ (t-statistics are in parentheses) } \\
\hline $\begin{array}{l}\text { N et Expected Dollar } \\
\text { D evaluation R elative } \\
\text { to the French Franc }\end{array}$ & $\begin{array}{c}0.11 \\
(2.00)\end{array}$ & $\begin{array}{c}0.84 \\
(11.14)\end{array}$ & $\begin{array}{l}-0.000 \\
(-0.229)\end{array}$ & 0.66 \\
\hline $\begin{array}{l}\text { N et Expected Dollar } \\
\text { D evaluation R elative } \\
\text { to the Swiss Franc }\end{array}$ & $\begin{array}{c}0.18 \\
(1.91)\end{array}$ & $\begin{array}{c}0.85 \\
(12.93)\end{array}$ & $\begin{array}{c}0.001 \\
(0.761)\end{array}$ & 0.74 \\
\hline $\begin{array}{l}\text { N et Expected Dollar } \\
\text { D evaluation R elative } \\
\text { to the D utch Guilder }\end{array}$ & $\begin{array}{l}0.08 \\
(1.46)\end{array}$ & $\begin{array}{c}0.81 \\
(9.66)\end{array}$ & $\begin{array}{c}0.001 \\
(0.496)\end{array}$ & 0.64 \\
\hline $\begin{array}{l}\text { N et Expected Dollar } \\
\text { D evaluation R elative } \\
\text { to the Belgian Belga }\end{array}$ & $\begin{array}{c}0.01 \\
(0.11)\end{array}$ & $\begin{array}{c}0.88 \\
(13.65)\end{array}$ & $\begin{array}{c}0.000 \\
(0.252)\end{array}$ & 0.77 \\
\hline
\end{tabular}


Figure 1

$\mathrm{N}$ et Expected D ollar Devaluation

a. Relative to the French Franc

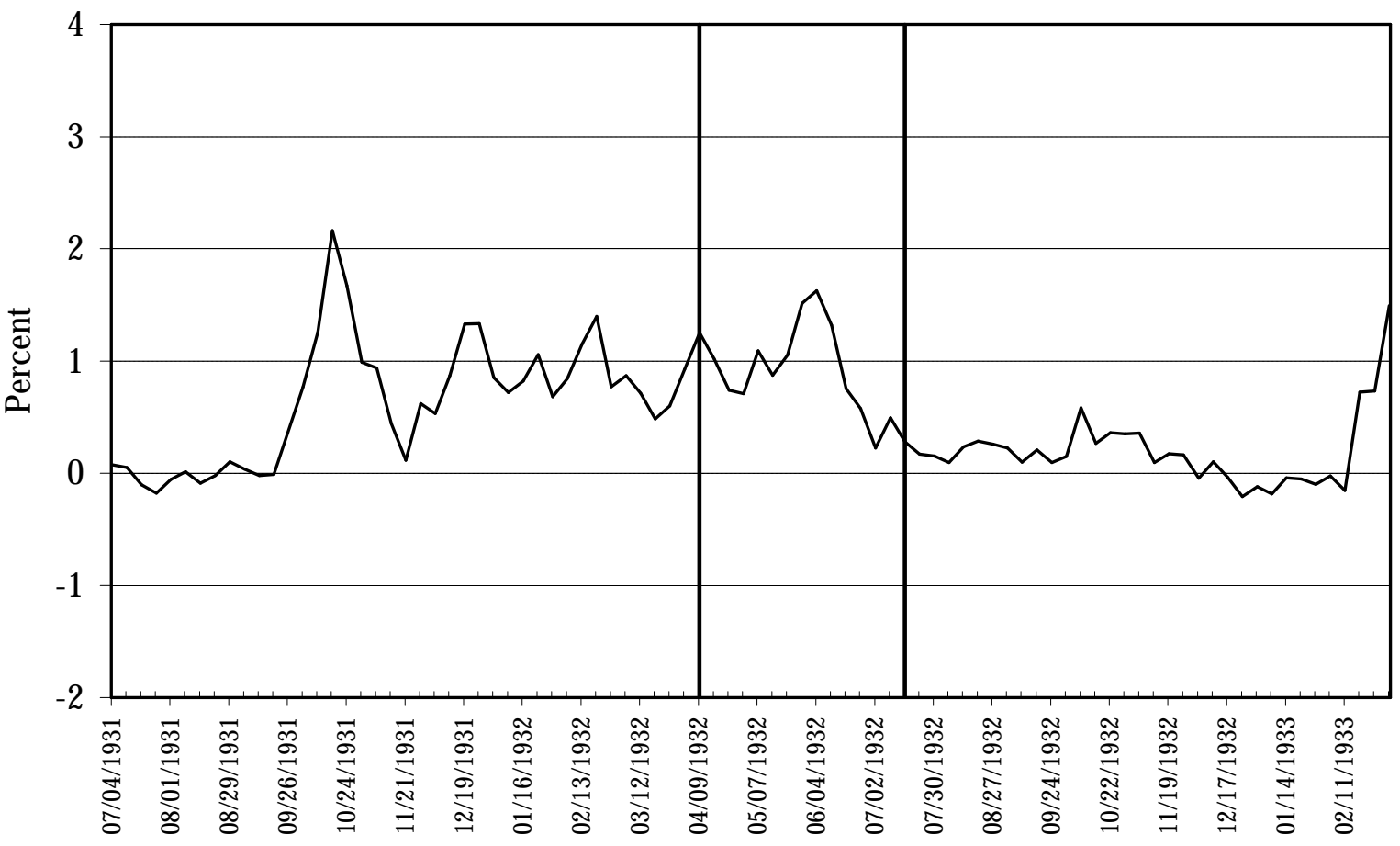

b. Relative to the Swiss F ranc

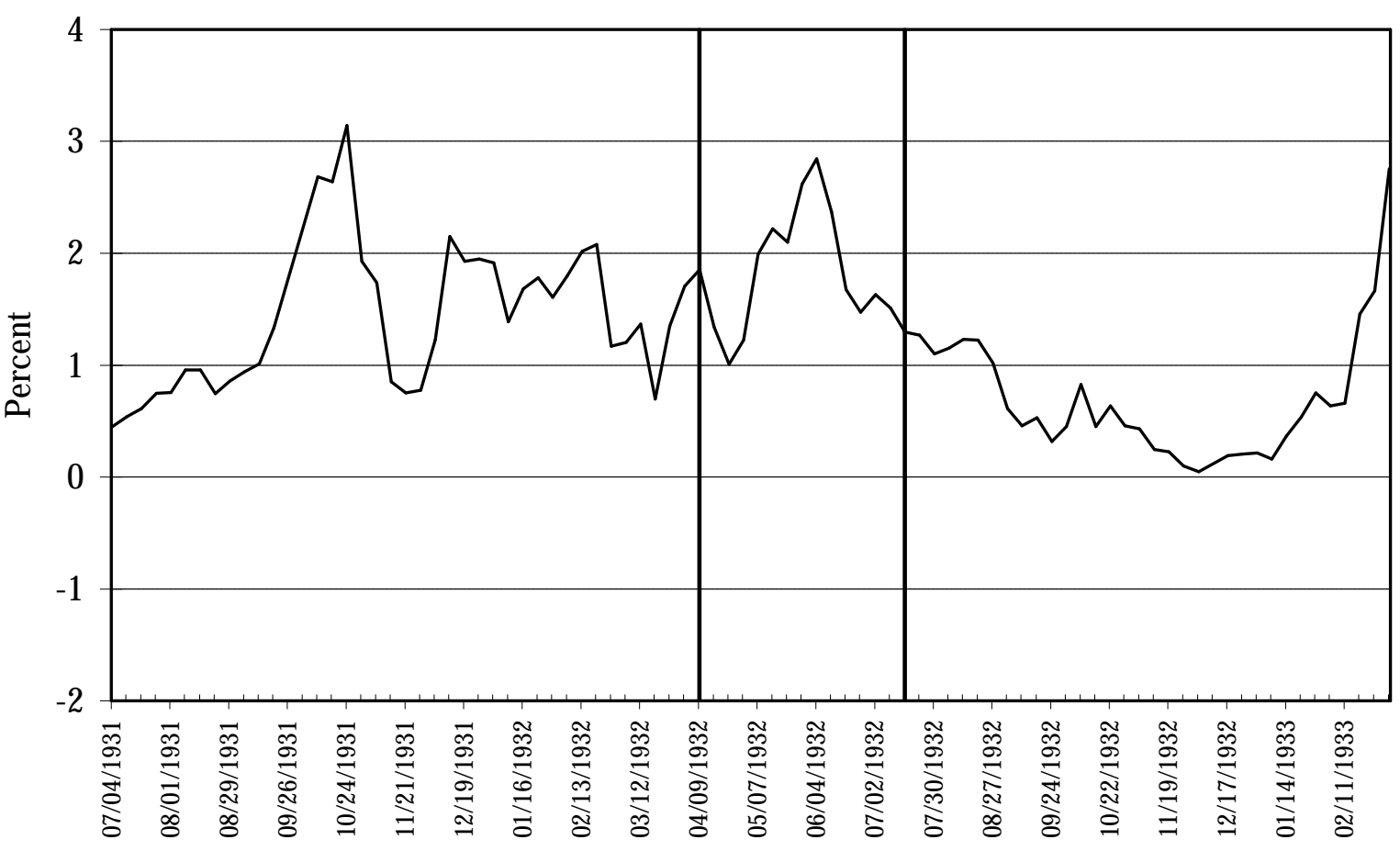


Figure 1, continued

$\mathrm{N}$ et Expected D ollar Devaluation

c. Relative to the Dutch Guilder

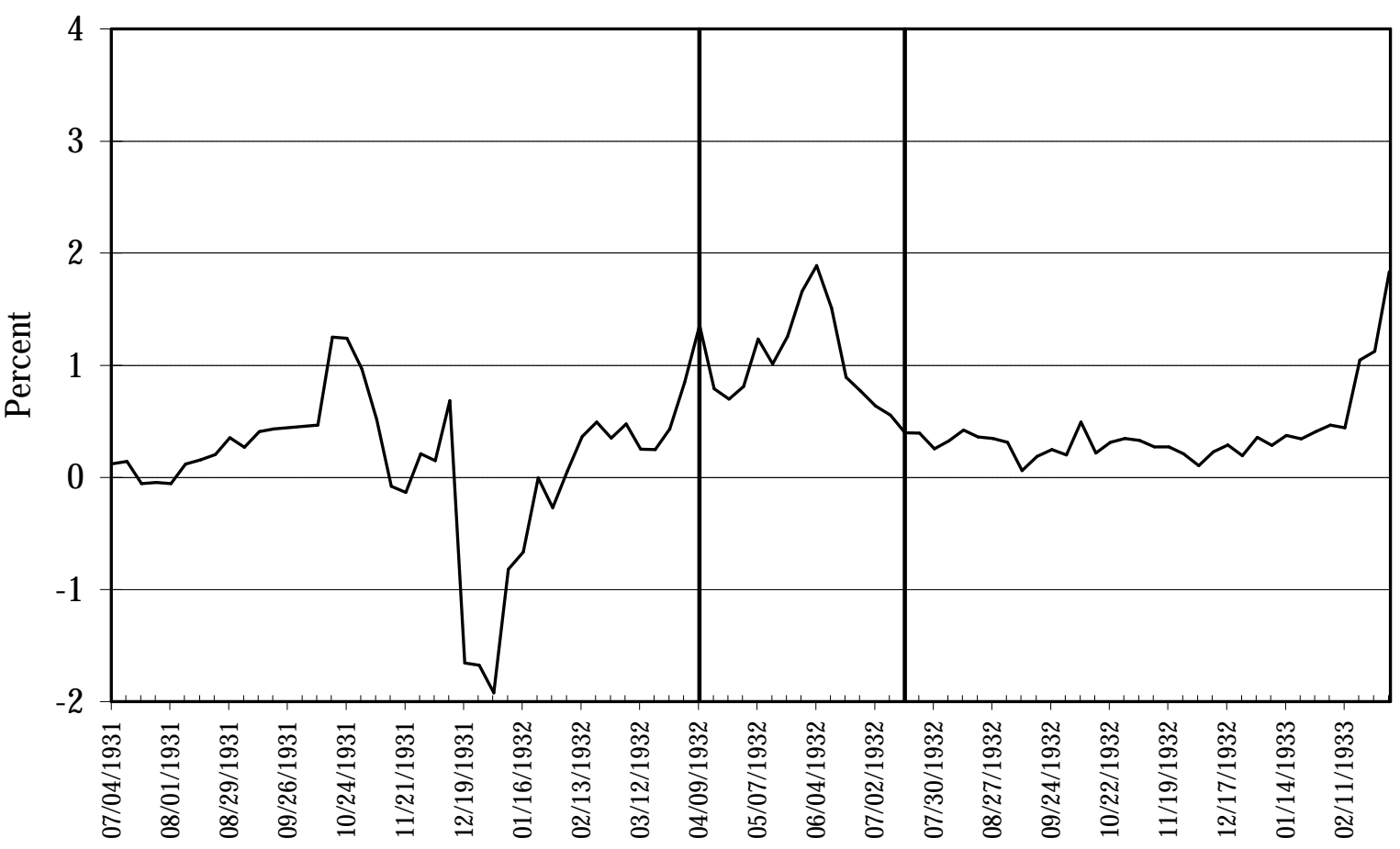

d. Relative to the Belgian Belga

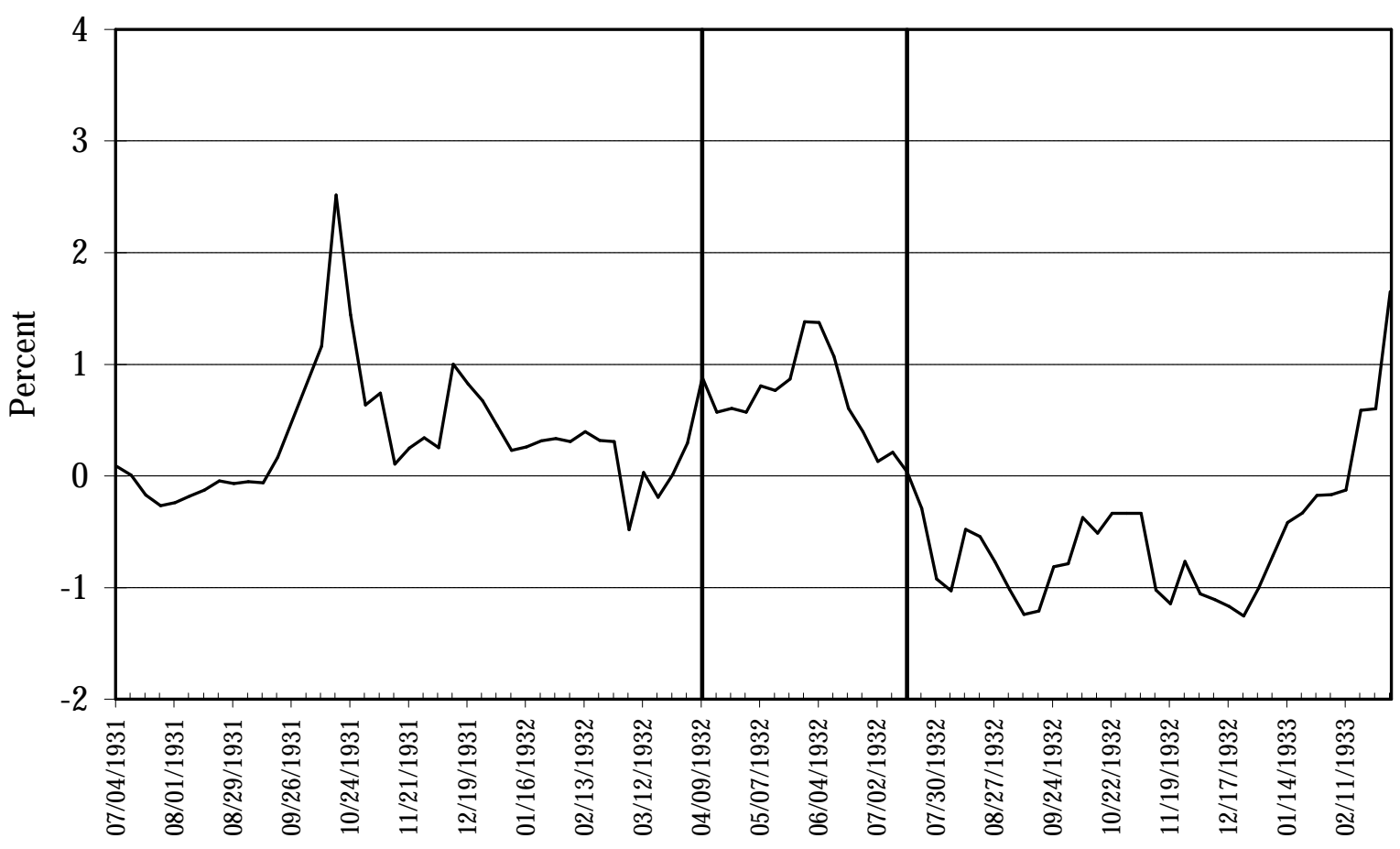


Figure 2

Federal Reserve Purchases of Government Securities

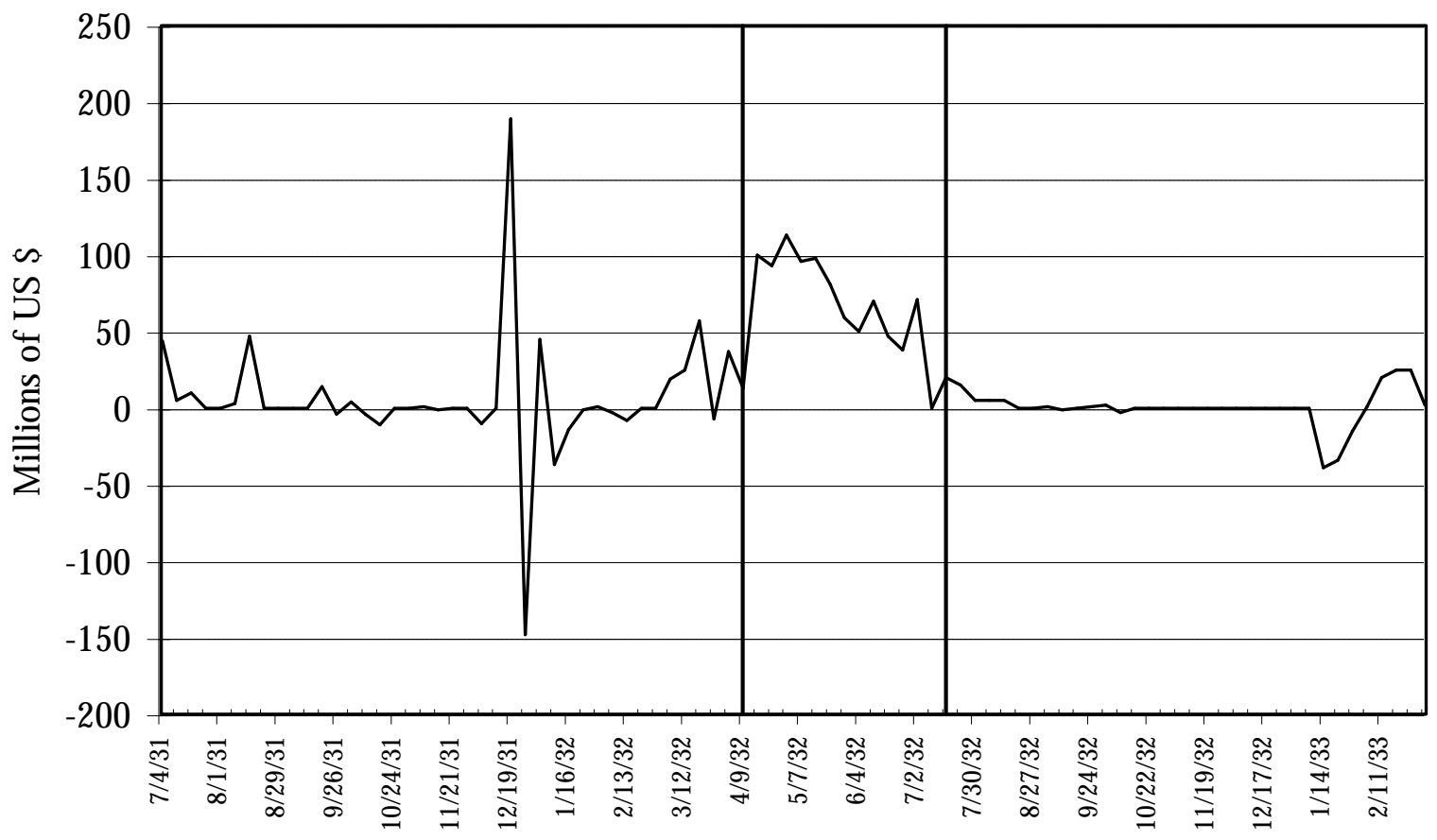


Figure 3

Simple Expected Dollar Devaluation

Relative to the French Franc

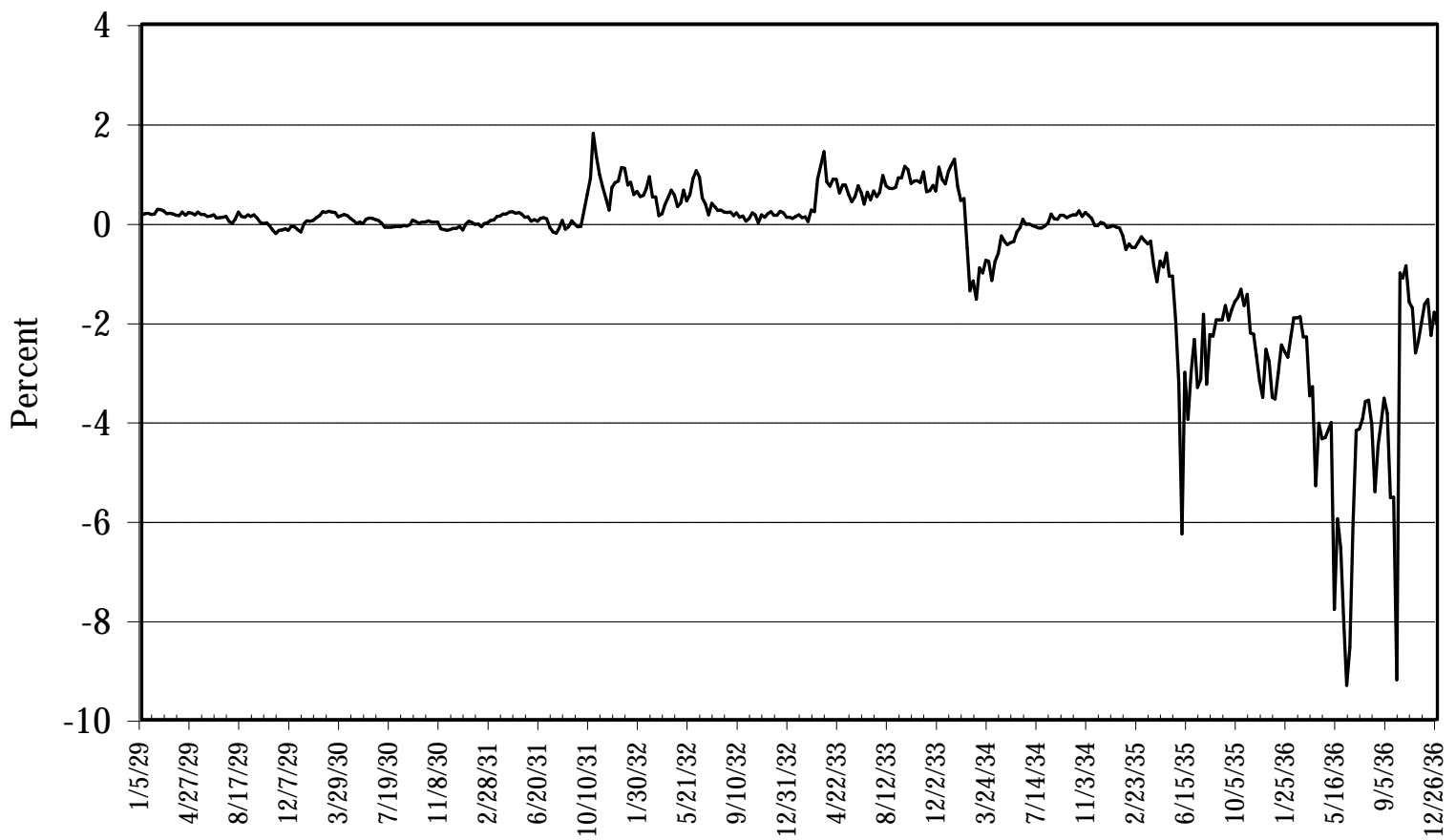


Figure 4

Interest Rate Differentials

(U.S. Rate M inus Foreign Rate)

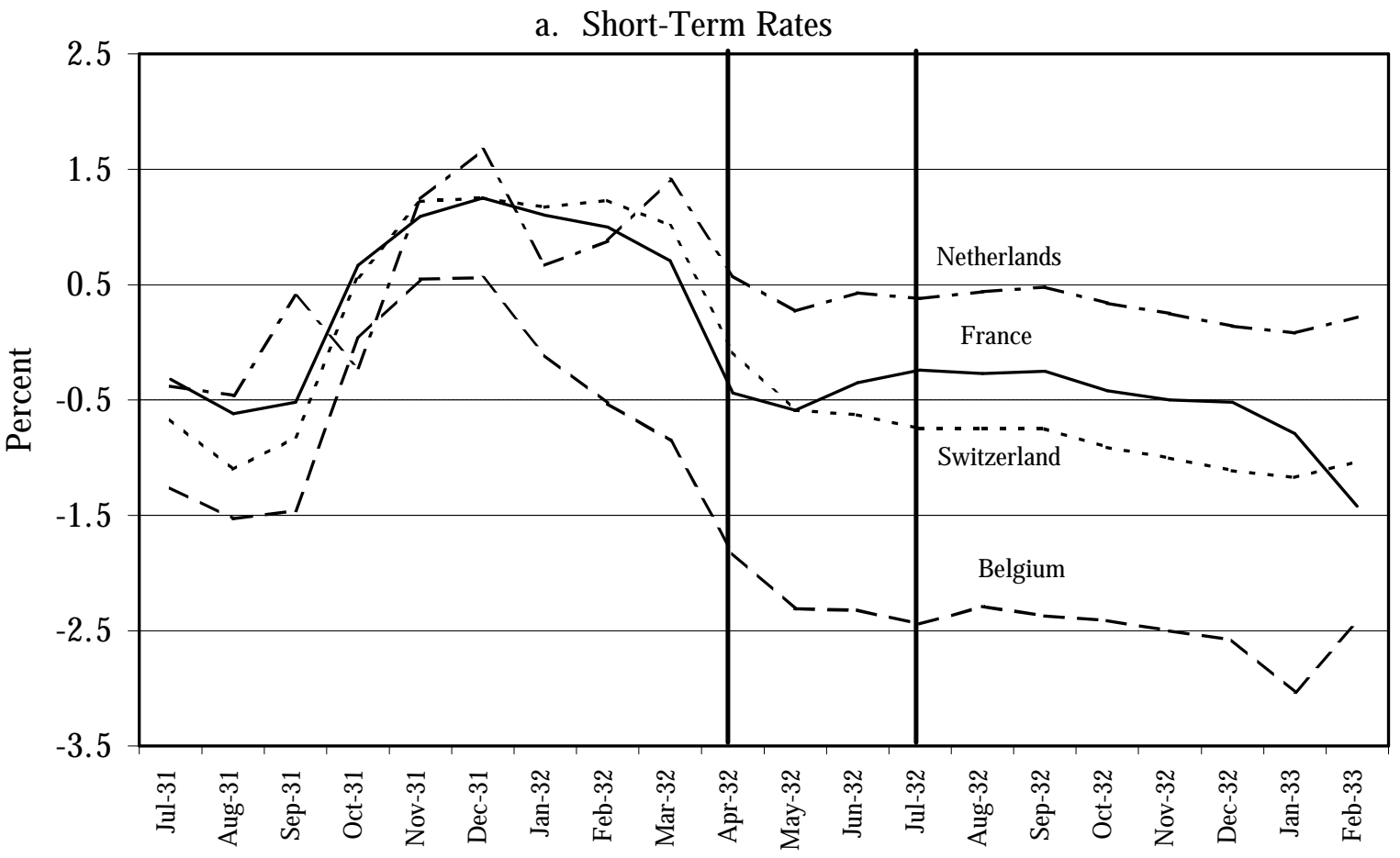

b. Long-Term Rates

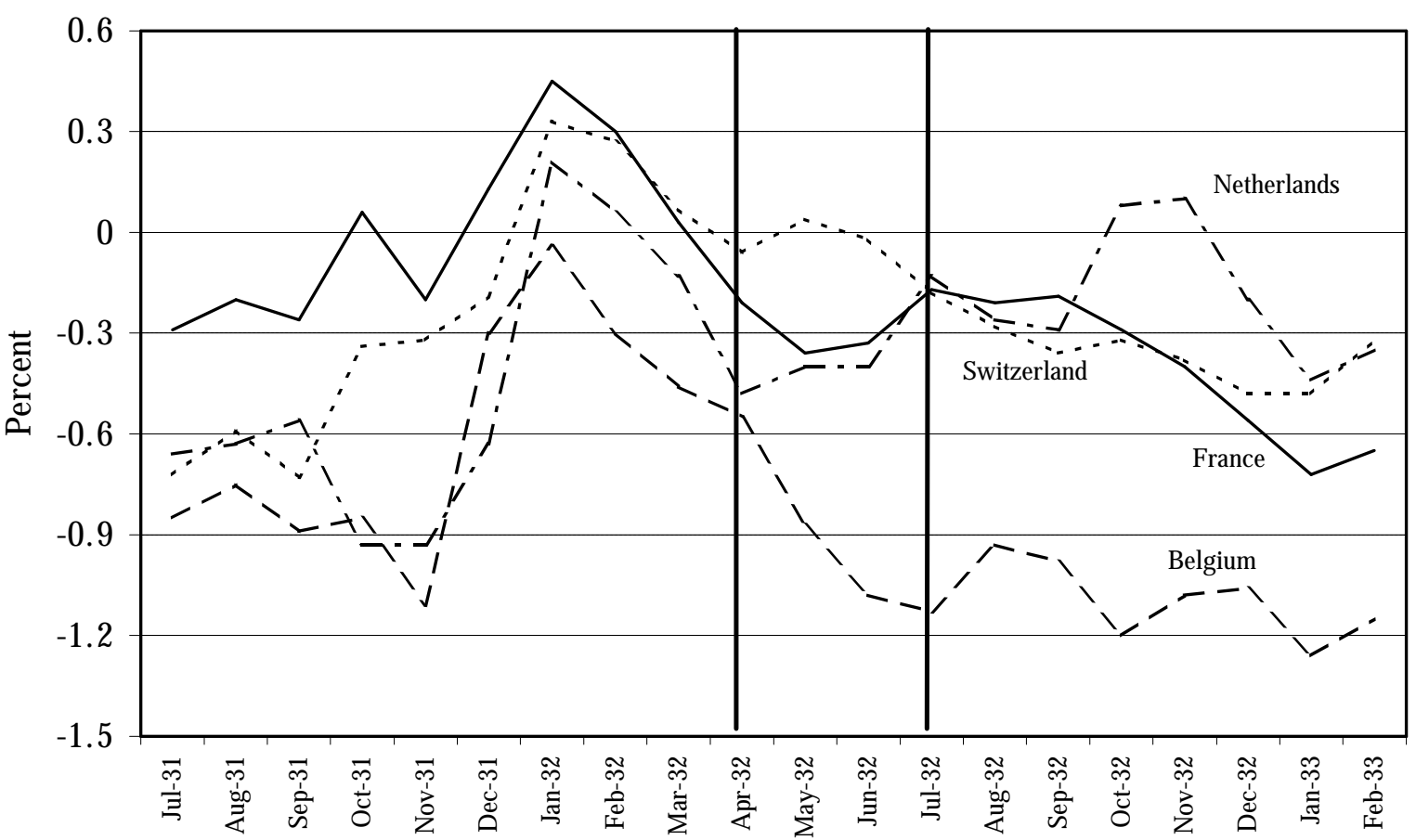


Figure 5

Index of Industrial Production

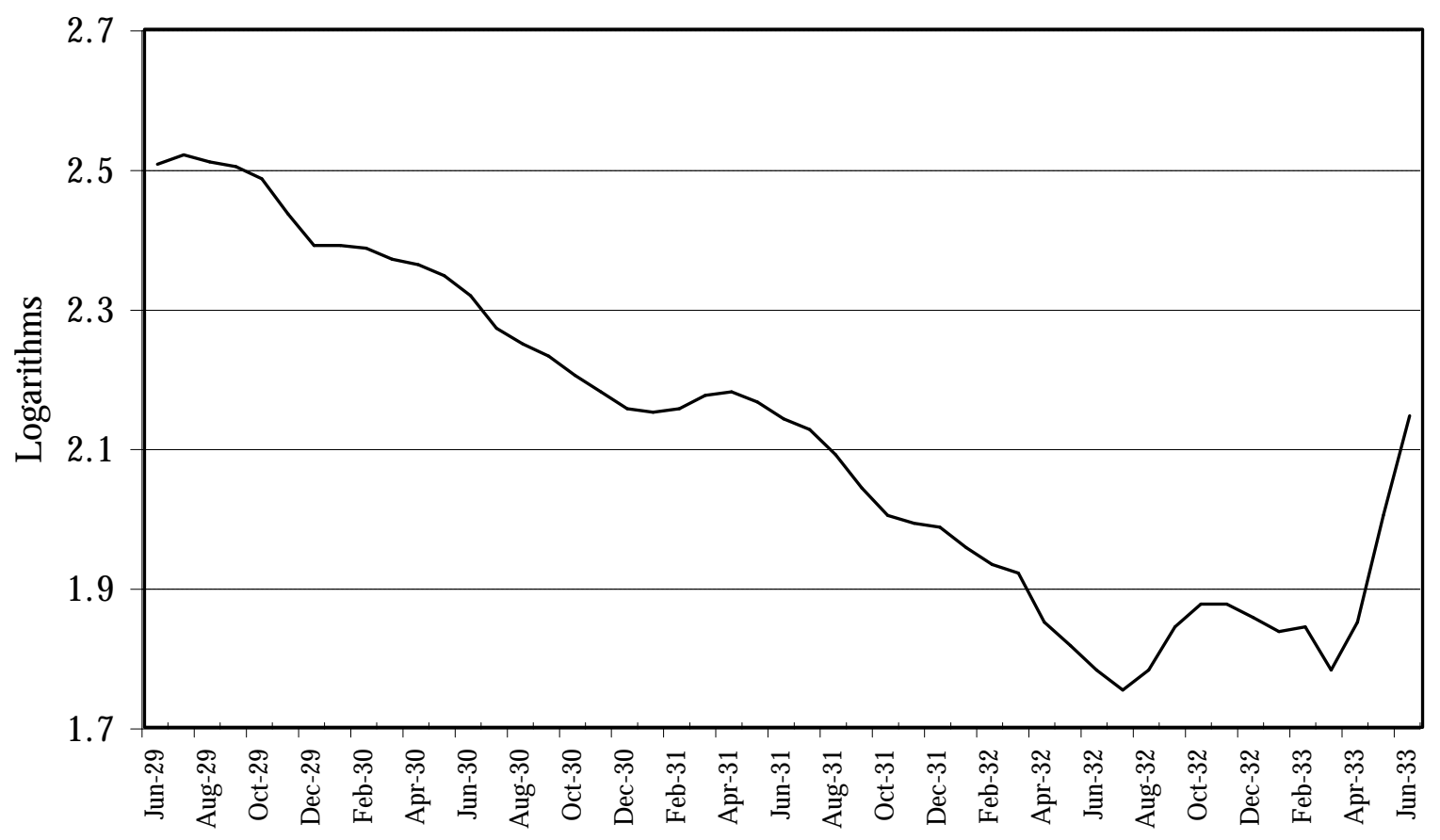


Figure 6

Estimates of the Real Short-Term Interest Rate

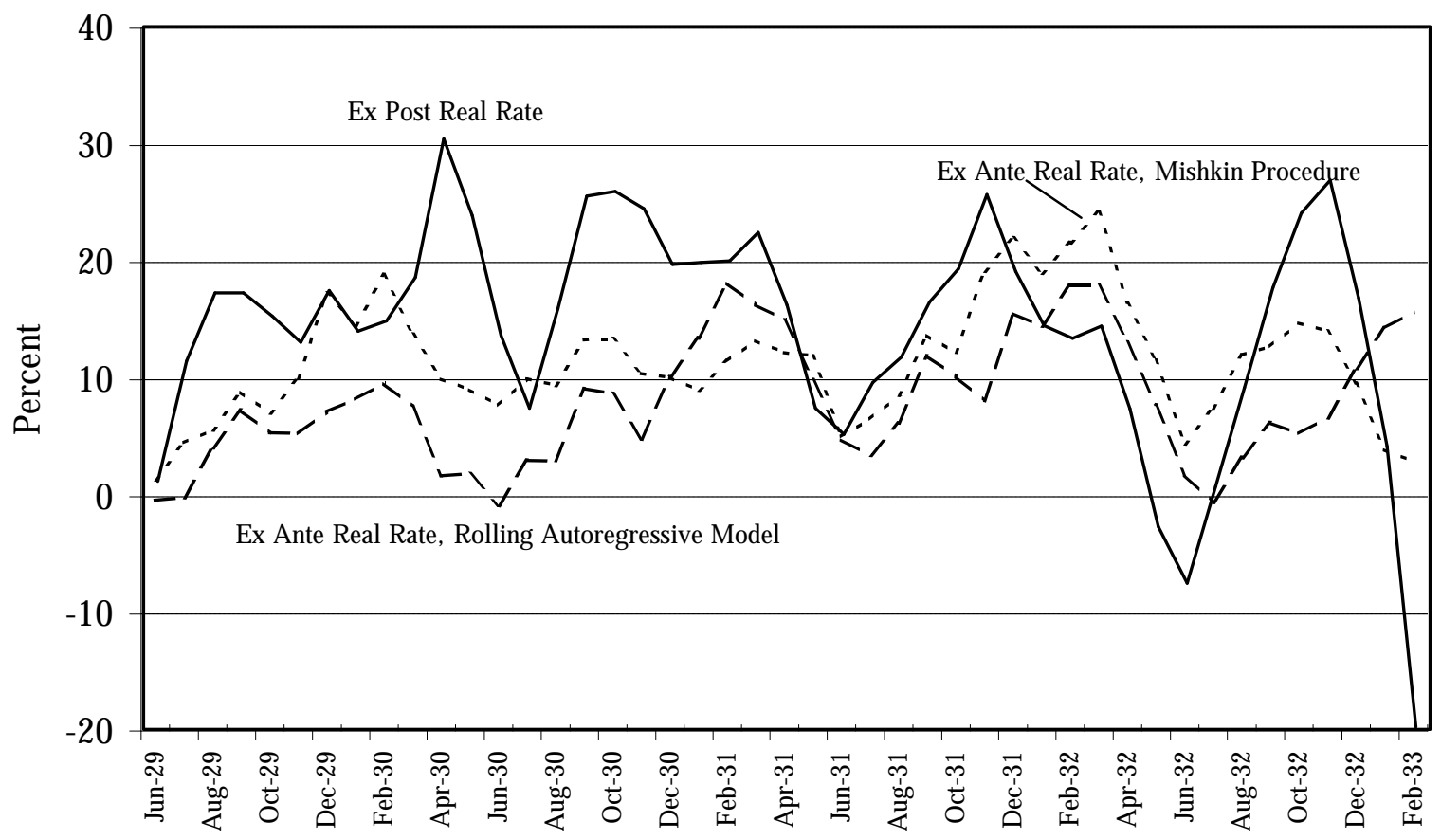


Figure 7

Retail Price of F ood

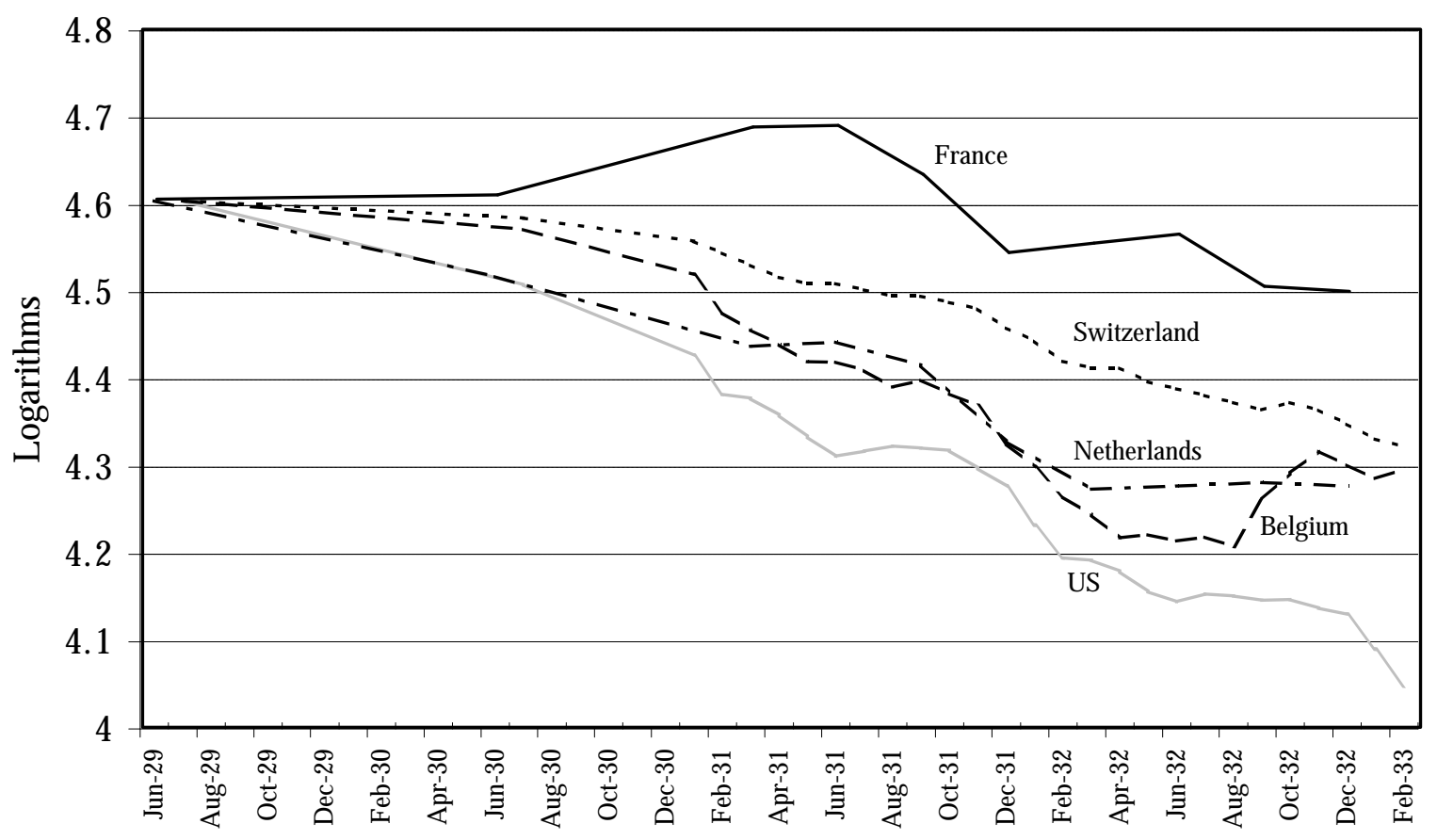


Figure 8

$N$ et Expected Dollar Devaluation Relative to the French Franc

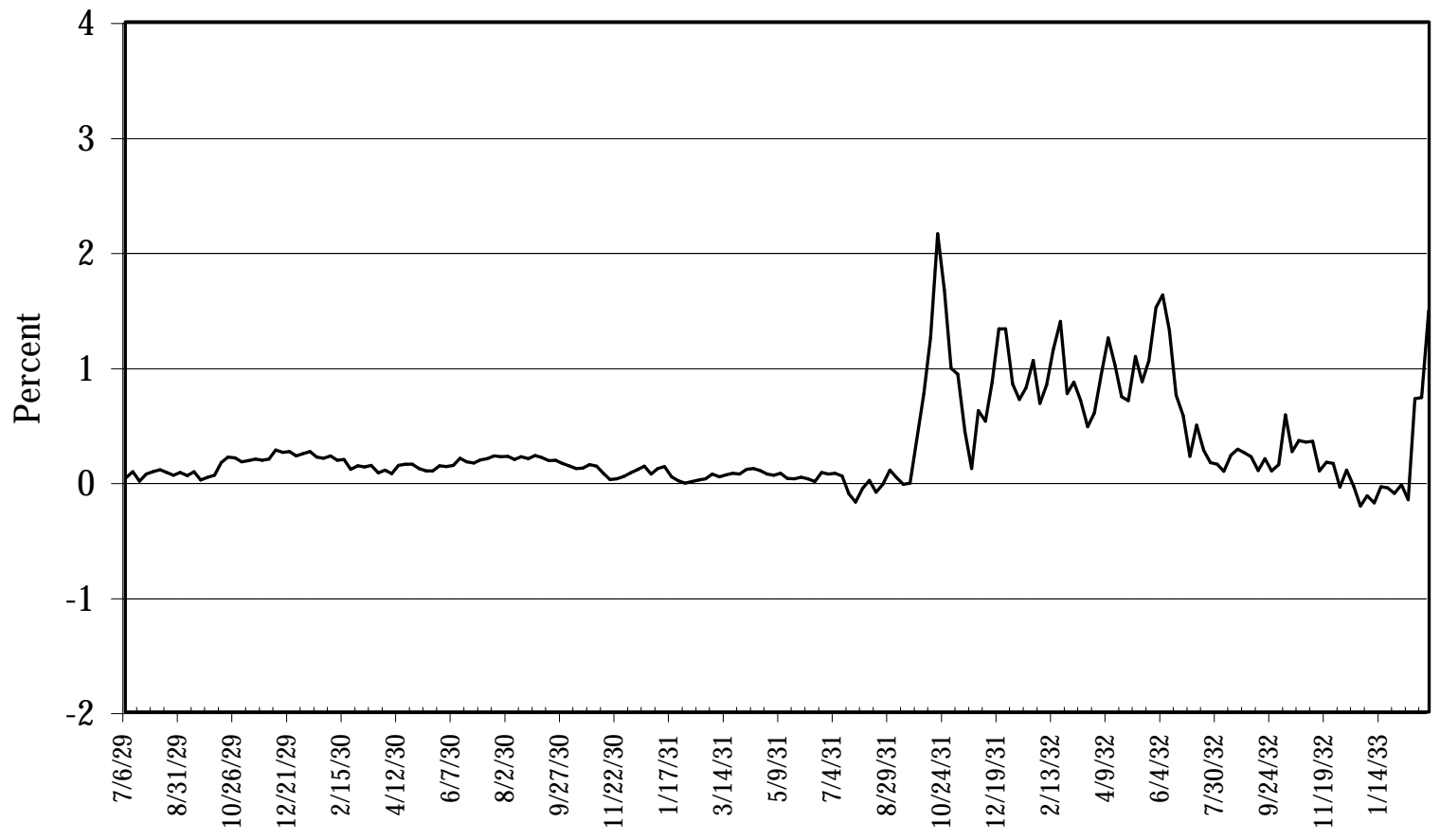

